Nguyen, V. K. T., Nguyen, D., Hoang, L. P., Nguyen, L. D., Tran, D. D., Anh, T. T., Kummu, M., Merz, B., Apel, H. (2020): Future projections of flood dynamics in the Vietnamese Mekong Delta. - Science of the Total Environment, 742, 140596.

https://doi.org/10.1016/j.scitotenv.2020.140596 


\title{
Future projections of flood dynamics in the Vietnamese Mekong Delta
}

Nguyen Van Khanh Triet ${ }^{1,2}$, Nguyen Viet Dung ${ }^{1}$, Long Phi Hoang ${ }^{3}$, Nguyen Le Duy ${ }^{1,2}$, Dung Duc $\operatorname{Tran}^{4,5}$, Tran Tuan Anh ${ }^{1,2}$, Matti Kummu ${ }^{6}$, Bruno Merz ${ }^{1,7}$, Heiko Apel ${ }^{1}$

$5 \quad{ }^{1}$ GFZ German Research Center for Geosciences, Section Hydrology, Potsdam, 14473, Germany

${ }^{2}$ SIWRR Southern Institute of Water Resources Research, Hochiminh City, 700000, Vietnam

${ }^{3}$ Water Systems and Global Change Group, Wageningen University, P.O. Box 47, 6700 AA Wageningen, the Netherlands

${ }^{4}$ Center of Water Management and Climate Change, Institute for Environment and Resources, Vietnam National 10 University - Ho Chi Minh City (VNU-HCM), Ho Chi Minh City, 700000, Vietnam

${ }^{5}$ Faculty of Environmental and Food Engineering, Nguyen Tat Thanh University, Ho Chi Minh City, 700000, Vietnam

${ }^{6}$ Water \& Development Research Group, Aalto University, P.O. Box 15200, Aalto, Finland

${ }^{7}$ Institute for Environmental Sciences and Geography, University of Potsdam, Potsdam, 14469, Germany

15 Correspondence to: Nguyen Van Khanh Triet (triet@gfz-potsdam.de)

\begin{abstract}
The annual flood pulse of the Mekong River is crucial to sustain agriculture production, nutrition, and the livelihood of millions of people living in the Vietnamese part of the Mekong Delta (VMD). However, climate change impacts on precipitation, temperature and sea-level combined with land subsidence, upstream hydropower development, and water infrastructures (i.e. high-dykes construction) are altering the hydrological regime of the VMD. This study investigates future changes in flood hazard and agricultural production caused by these different scales of human-induced stresses. A quasi- two-dimensional (quasi-2D) hydrodynamic model was used to simulate eight scenarios representing the individual and compound impacts of these drivers for a baseline (1971-2000) and future (2036-2065) period. The scenarios map the most likely future pathway of climate change (RCP 4.5) combined with

25 the best available Mekong upstream hydropower development, and land subsidence scenarios as well as the current delta development plan. We found that sea-level rise and land subsidence would cause the highest changes in flood hazard and damage to rice crop, followed by hydropower and climate change impacts. Expansion of high-dyke areas in two northernmost delta provinces (An Giang and Dong Thap) would have the smallest impact. The combination of all modelled drivers is projected to increase delta inundation extent by $20 \%$, accompanied with prolonging

30 submergence of 1-2 months, and 2-3 times increase in annual flood damage to rice crops in the flood-prone areas of the VMD. These findings of likely increasing risk of tidal induced flood hazard and damage call for well-planned adaptation and mitigation measures, both structural and non-structural.
\end{abstract}




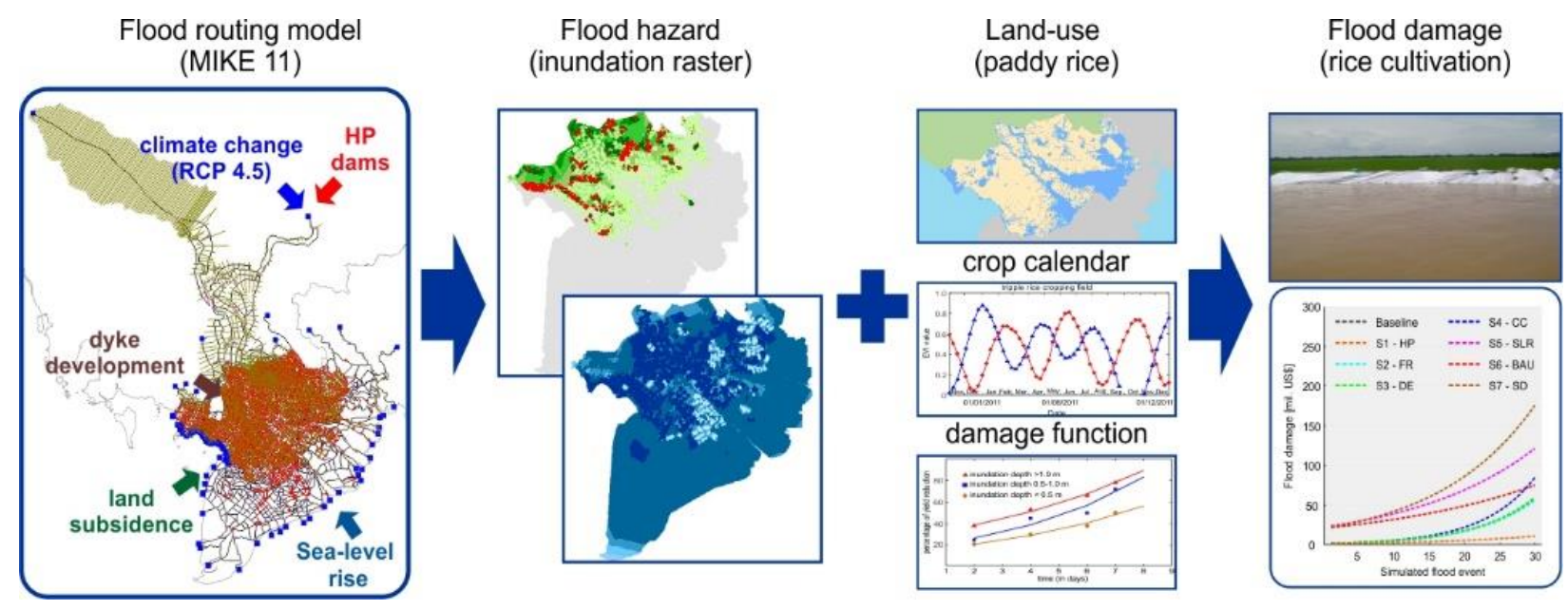

\section{Highlights}

- Climate change, hydropower, dyke development, sea-level rise and delta land subsidence strongly alter the delta future flood hazard and damage.

- Higher flood extent (22-26\%) and prolong inundation (1-2 months) are mainly driven by effective sea-level rise and climate change.

- Hydropower development might counteract the increase flood hazard and damage driven by climate change.

- A reliable seasonal flood forecast (by August) would effective help to minimize agriculture flood damage.

- Emerging call to develop flood management plan with focus on tidal induce inundation hazard.

\section{Keywords}

Hydrodynamic modelling, Hydropower, Climate change, Sea-level rise, Land subsidence 


\section{Introduction}

World river deltas comprise less than $1 \%$ of the Earth's landmass, but they are home for over 500 million inhabitants (Ericson et al., 2006). Further, many deltas are the key source of regional and even global nutrition due to their rich ecological systems (e.g. fishery), and fertile soils supporting food production. Yet their residents face imminent threats of floods, losses of landmass, pollution, and saline water intrusion. These threats will become even larger under climate change and development activities (e.g. Hirabayashi et al., 2013; Tessler et al., 2015), and will challenge national to global food security (Nelson et al., 2010; Kummu et al., 2012). In the light of these outlooks, this study aims to give insights on future flood dynamics under multiple future drivers in the Vietnamese Mekong Delta (VMD), the world's third-largest coastal floodplain, which is essential to the food production and security of Vietnam.

The VMD is home for 18 million people; it contributes over $50 \%$ of the country's food production, and over $80 \%$ of Vietnam's exported rice (GSO, 2015). Livelihoods of millions of delta residents depend on the annual flood pulse of the Mekong River. While extreme floods can cause excessive damages and losses (e.g. estimated economic losses from the historical flood in 2000 were US\$ 250 million, and over 450 fatalities (Kreibich et al., 2017)), the annual flood benefits in the Lower Mekong Basin (LMB) are estimated at US\$ 8-10 billion on average (MRC, 2012). Replenishing soil nutrients, support of the ecological system, provision of sediment to counter deltaic land compaction and erosion are some of the well-acknowledged flood benefits (Manh et al., 2014). Understanding delta flood dynamics is an important, yet highly challenging task to ensure safety and sustainable development of the region.

The VMD with its extreme low mean elevation $\sim 0.8 \mathrm{~m}$ (Minderhoud et al., 2019) is one of the globally most vulnerable deltas to climate change and sea-level rise (Tessler et al., 2015). Recent climate impact projections revealed an intensification in magnitude (Lauri et al., 2012; Hoang et al., 2018) and frequency of extreme floods (i.e. the 100-year flood) in the Mekong River basin (Hirabayashi et al., 2013). The Fifth Assessment Report of the Intergovernmental Panel on Climate Change predicted an increase of 17-38 cm in tidal level along the coast of the VMD by mid-century (IPCC, 2014).

In addition to the climate-related factors, anthropogenic interventions both locally and upstream would likely alter the flood dynamics of the VMD. Locally, the deltaic land subsidence amplifies the rising sea-level; the VMD is rapidly sinking at rates of 1.0-2.5 $\mathrm{cm} \mathrm{yr}^{-1}$ because of unsustainable groundwater extraction, which is expected to continue in the future. This will increase the risk in both fluvial and tidal induced floods (Erban et al., 2014; Minderhoud et al., 2017). Further, the development of local water infrastructures also contributes to the alteration of delta inundation dynamics. The construction of high-dykes and sluice gates have been the conventional flood management approach in the VMD (Hung et al., 2012; Tri, 2012). These structures prevent protected areas from being flooded and thus reduce flood hazard within the protected areas; however, they divert the flood hazard to neighbouring, mostly downstream communities (e.g. Triet et al., 2017; Tran et al., 2018b). Besides, sand mining in the LMB is likely to increase flood risk in the VMD (Hackney et al., 2020).

In upstream part of the Mekong Basin, hydropower development affects the hydrological regime and flood pulse of the Mekong (Lauri et al., 2012; Räsänen et al., 2017; Hecht et al., 2019). The Mekong River Commission estimates the basin's active reservoir storage in 2025 would reach $86.8 \mathrm{~km}^{3}$, about $19 \%$ of the mean annual flow of the Mekong (MRC, 2015). Note that the estimation from MRC does not include data of the existing and planned dams in China; with the active reservoir storage from the existing dams amounts to $23.0 \mathrm{~km}^{3}$ (Räsänen et al., 2017). Besides altering 
the flow regime of the Mekong as reported in Räsänen et al. (2017), there are concerns about serious impacts on ecosystems (Ziv et al., 2012; Arias et al., 2014), on sediment dynamics (Kummu et al., 2010; Manh et al., 2015; Kondolf et al., 2018), and on the livelihoods of millions of delta inhabitants (Pearse-Smith, 2012).

Although impacts of individual drivers to the VMD have been studied (e.g. Le et al., 2007; Van, 2009; Van et al., 2012; Triet et al., 2017; Dang et al., 2018; Tran et al., 2018b), the compound impacts of all drivers on flood hazard have not been quantified. Moreover, the compound impacts in terms of damage to agriculture crops have not been assessed yet. Dang et al. (2018) investigated changes in the hydrological regime driven by hydropower development, land subsidence, sea-level rise, and local water infrastructure development in the VMD; the authors, however, neither considered climate change nor the cumulative impacts of all drivers. Van et al. (2012), in turn, studied the delta inundation regime in response to climate change using the projected future Mekong streamflow from Hoanh et al. (2010); arguably this dataset is highly uncertain, because only a single Global Circulation Model (GCM) was used (taken from Lauri et al., 2012). To fill this knowledge gap, in this study we aim to provide future projections of flood dynamics in the VMD driven by (i) climate change impacts on precipitation and temperature along the Mekong, (ii) sea-level rise plus deltaic land subsidence (so-called effective sea-level rise), (iii) upstream hydropower development, and (iv) development of local water infrastructures. We consider both the individual and cumulative impacts in a set of model simulations of flood dynamics in the Mekong Delta, using state-of-the art hydrodynamic model MIKE 11. Besides, our study provides an estimation on changes in flood damage to rice cultivation, the predominant land-use type in the region.

\section{Regional setting}

The Vietnamese Mekong Delta (VMD) covers a land area of around 40,000 $\mathrm{km}^{2}$ in the southernmost tip of Vietnam between $8.5-11.5^{\circ} \mathrm{N}$ and $104.5-106.8^{\circ} \mathrm{E}$. On average, annually $475 \mathrm{~km}^{3}$ of the Mekong flow routes through the VMD between 1 June and 30 November, submerging 35-50\% of the delta with inundation depths up to $4.0 \mathrm{~m}$ for 2-5 months (Toan, 2014). This flood-prone area of the VMD is commonly distinguished into deep and shallow submergence regions based on inundation depth, i.e. above/less than 1.5 meter (right panel of Fig. 1). A dense network of natural and man-made channels intersects the delta and separates it into thousands of compartments enclosed by channels. Dykes, sluice gates and pumps are added to protect the compartments against floods or saline water intrusion. There are two types of dykes which are referred to as "low-dyke" and "high-dyke". Low-dykes often have crest levels around 2.5 a.m.s.l., retaining floodwater from the first flood peak until about mid-August to support the double season rice crop cultivation per year. High-dykes have crest level at 4.5 a.m.s.l. on average; therefore, floodplains protected with high-dykes can be cut off from the natural inundation regime, enabling the cultivation of a third rice crop during the flood season. The operation of sluice gates, and pumping stations control the water flow in and out of these compartments (Hung et al., 2012). Hence, the floodplain processes in the VMD are a result of a complex hydrodynamic interaction of fluvial dynamics, tidal influence, and operation of delta water infrastructures. 

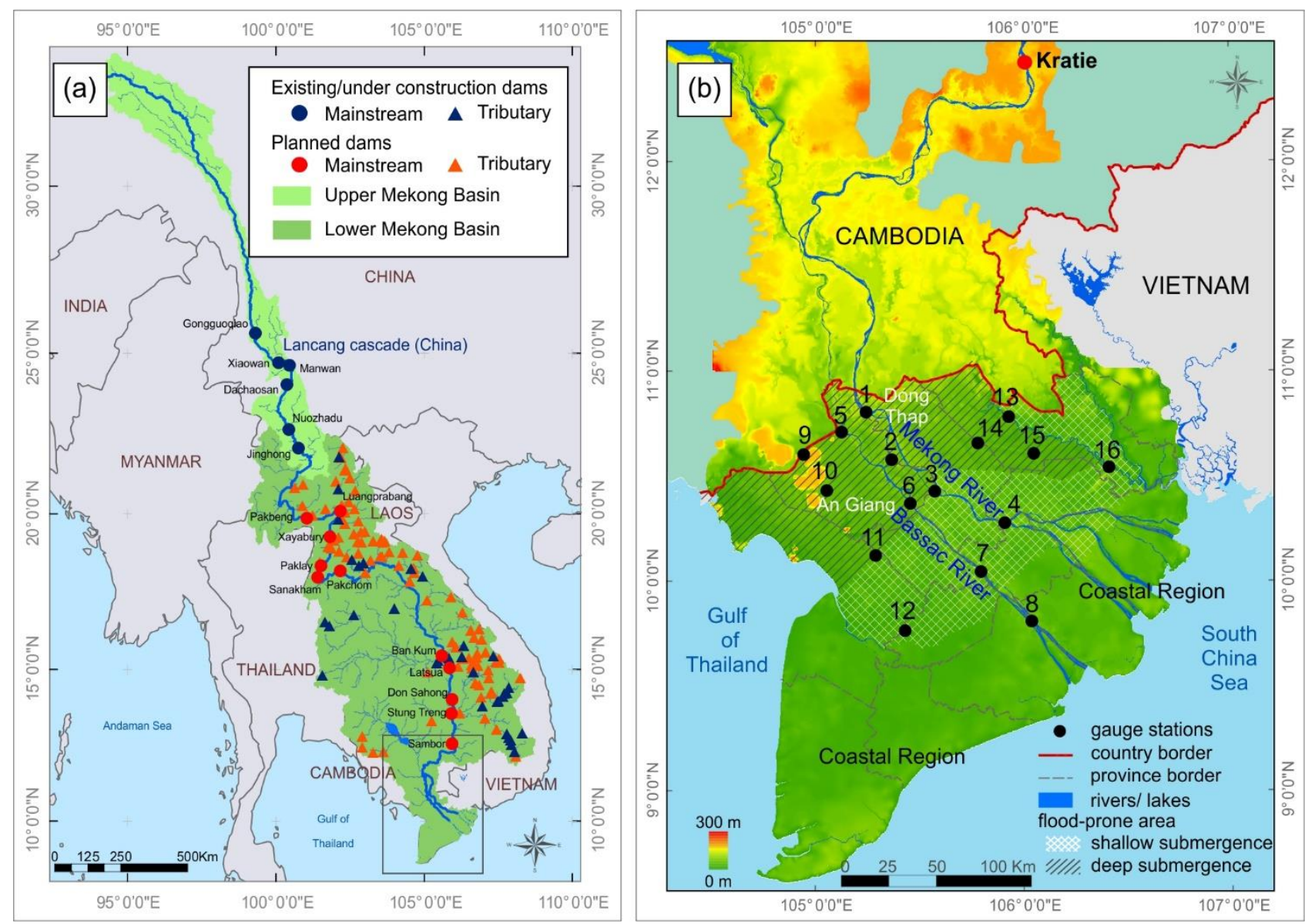

Figure 1: (a) Mekong River Basin and location of hydropower projects (Hoang et al., 2018). (b) The Mekong Delta from Kratie (red dot) to the sea and location of hydrological stations, the Vietnamese Mekong Delta, and its flood-prone, deep and shallow, regions.

\section{Methodology}

\subsection{Flood propagation model}

The presented work modelled the Mekong Delta flood dynamics with the MIKE 11 software developed by the Danish Hydraulic Institute (DHI) (https://www.mikepoweredbydhi.com/). The model structure was initially developed and calibrated by Dung et al. (2011), and have since been continually updated and applied to evaluate flood hazard and damage (Triet et al., 2017; Triet et al., 2018), and sedimentation dynamics (Manh et al., 2014; Manh et al., 2015). The calibration and validation of this flood propagation model covered a wide spectrum of flood events, including high flood events (e.g. in 2000, 2011), a normal flood event as occurred in 2009, and a low flood year as in 2010 (Triet et al., 2017). Figure S1 in the Supplement exemplifies the calibration results for the two recent extreme floods in 2000 and 2011. The model set up, calibration, and validation are described in detail in the cited references.

We adopted the latest model setup of Triet et al. (2017). The model domain covers an area of 55,000 $\mathrm{km}^{2} \mathrm{of} \mathrm{the}$ Mekong floodplain downstream of Kratie in Cambodia, including the Tonle Sap lake system (Fig. 2b). Triet et al. (2017) model floodplain inundation process within the one-dimensional modelling software MIKE 11 using virtual branches with wide cross-sections extracted from a digital elevation model (DEM). The dykes enclosing the floodplain compartments are introduced in the model structure as broad crest weirs, with crest levels reflecting dyke height (Fig. 2c). Other flood control structures, e.g. weirs, dams, are also incorporated whenever information is available. The 
model network comprises 4,000 channels and 2,500 control structures. A complete simulation of one flood event of six months (1 June -30 November) requires 2-3 hours on a local PC.

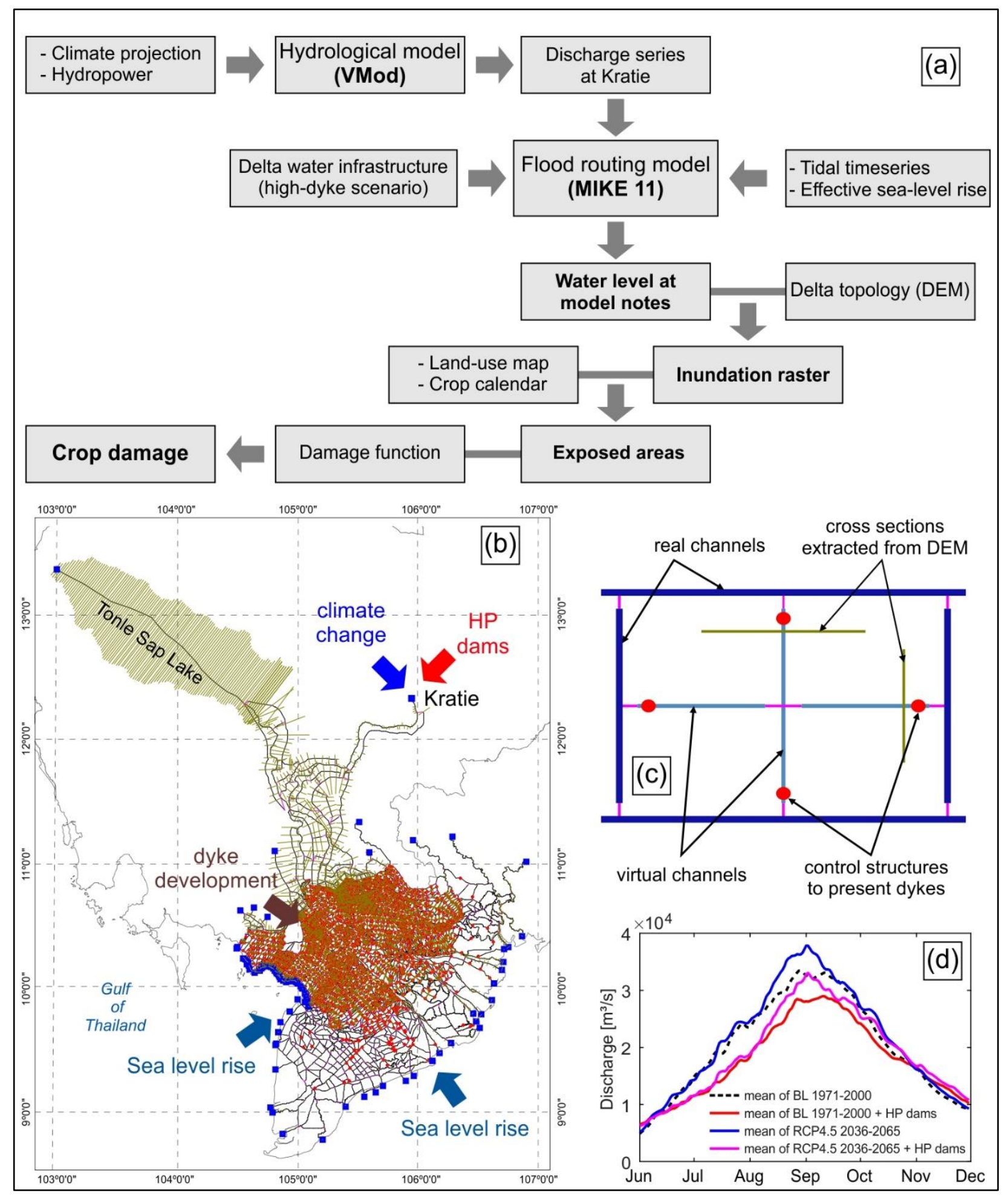

Figure 2. (a) Flowchart for the applied methodology to estimate changes in flood dynamics in the VMD. (b) Channel network of the large-scale quasi-2D flood propagation model, and locations where the different drivers affect as considered in the model. (c) Scheme illustrating the modelling of 2-D floodplain inundation and dyke system in the $1 D$ modelling package MIKE 11. (d) Mean baseline and projected future discharge series at Kratie, based on data of Hoang et al. (2018) and calculated as the mean of the 30-year daily discharge of the baseline and future periods. 


\subsection{Transformation of simulated water levels to flood hazard and damage to rice crop}

We adapted the approach proposed in Triet et al. (2018) to compute and assess changes in flood hazard and the related damage to rice cropping in the VMD, as summarised here. At first, they produce water level raster maps from simulated results at model nodes with the Inverse Distance Weighting (IDW) tool in ArcGIS. Raster maps of inundation are computed by intersecting the interpolated water level maps with the DEM of the VMD. To estimate damage to rice cultivation, Triet et al. (2018) generate three inundation raster maps for each modelled flood event using maximum modelled water levels of three time slices: 1 June - 31 July, 1 June - 15 September, and 1 June -30 November. The reason for these time slices is the spatial differentiation of rice cropping, i.e. double or triple season rice and different planting calendar in the different regions of the VMD (deep submergence, low submergence, coastal areas). For example, the inundation maps of 1 June - 15 September are used to compute flood exposure and damage to the Autumn-Winter crop (AWC) planted in the shallow submergence region; while for the AWC grown in the deep submergence region, the gridded inundation maps 1 June - 30 November are applied. They compute the exposed area $(E A)$ of rice crop to inundation by intersecting the land-use data with these flood hazard maps. Monetary flood damage $(E D)$ is calculated following eq. 2 in Triet et al. (2018). The whole procedure is automated with Python scripts (Python version 2.7), and the ArcPy module embedded in ArcGIS (version 10.4). See Triet et al. (2018) for more details.

\subsection{Simulation scenarios}

We set up eight scenarios (summarized in Table 1) to assess possible changes in flood hazard driven by (1) hydropower dam development in the entire Mekong Basin, (2) changes in flood control infrastructure in the VMD, (3) river flow influenced by climate change, (4) sea-level rise and deltaic land subsidence, i.e. "effective sea-level rise". We first modelled impacts of individual drivers, followed by their cumulative impacts. In each scenario, flood hazard was quantified using the quasi-2D model, which was driven by a 30-year flow series at Kratie. As the focus of the study is on flood hazard and damage, only the flood season from June to November was simulated for each year in the 30 -year period.

Baseline (BL): the BL scenario used the 1971-2000 discharge series at Kratie as the upstream boundary condition, matching the baseline period of Hoang et al. (2018). Because the complete timeseries of tidal levels for this period were not available, the average hourly tidal levels of the period 1971-2000 were used as downstream boundary condition. The dyke system as surveyed in 2009 and 2010 was implemented in the hydrodynamic model representing the present state of infrastructure development.

Hydropower development (S1-HP): the flow series at Kratie was simulated as consequences of all hydropower dams on the baseline flow (i.e. period 1971-2000 + all planned dams realized).

Floodplain restoration $(\mathbf{S 2 - F R})$ and High-dyke expansion $(\mathbf{S 3 - D E})$ : these two scenarios represent changes in local water infrastructure according to two development plans for the VMD proposed in Deltares (2013) in the Mekong Delta plan. S2-FR aims at enhancing flood storage capacity, as floodwater is stored in a large number of floodplain compartments protected by high-dykes in An Giang and Dong Thap provinces (Fig. 1b) during high flood phase, i.e. September-October, in order to reduce the flood hazard downstream. On the contrary, S3-DE assumes expansion of high-dyke protected floodplains in these two provinces to support the expansion of triple rice crop cultivation, following the "Food Production Scenario". 
Table 1. Scenarios used to investigate the impacts of climate change, hydropower development, sea-level rise and subsidence, and delta water infrastructure on flood dynamics in the VMD

\begin{tabular}{|c|c|c|c|c|c|}
\hline Name & Scenario description & $\begin{array}{l}\text { Climate change } \\
\text { impact }\end{array}$ & $\begin{array}{l}\text { Hydropower } \\
\text { impact }\end{array}$ & $\begin{array}{l}\text { Change in } \\
\text { tidal level }\end{array}$ & $\begin{array}{l}\text { Changes in delta } \\
\text { dyke system }\end{array}$ \\
\hline BL & $\begin{array}{l}\text { Simulated baseline conditions (1971-2000) + dyke } \\
\text { system in VMD as survey data of 2009-2010 }\end{array}$ & $\mathrm{N}^{\mathrm{a}}$ & $\mathrm{N}$ & $\mathrm{N}$ & $\mathrm{N}$ \\
\hline S1-HP & $\begin{array}{l}\text { Hydropower Development: Baseline conditions plus the } \\
\text { impacts of hydropower development }\end{array}$ & $\mathrm{N}$ & $\mathrm{Y}$ & $\mathrm{N}$ & $\mathrm{N}$ \\
\hline S2-FR & $\begin{array}{l}\text { Floodplain Restoration: Baseline condition plus open } \\
\text { "high-dyke" compartments in two delta provinces: An } \\
\text { Giang and Dong Thap to provide flood storage. }\end{array}$ & $\mathrm{N}$ & $\mathrm{N}$ & $\mathrm{N}$ & $Y(1)^{b}$ \\
\hline S3-DE & $\begin{array}{l}\text { Dyke Expansion (DE): Baseline condition plus the } \\
\text { expansion of "high-dyke" compartments in An Giang } \\
\text { and Dong Thap to maximize food production. }\end{array}$ & $\mathrm{N}$ & $\mathrm{N}$ & $\mathrm{N}$ & $\mathrm{Y}(2)^{\mathrm{c}}$ \\
\hline S4-CC & $\begin{array}{l}\text { Climate Change: Climate change scenario from MPI- } \\
\text { ESM-LR (2036-2065) and RCP4.5 }\end{array}$ & $\mathrm{Y}$ & $\mathrm{N}$ & $\mathrm{N}$ & $\mathrm{N}$ \\
\hline S5-SLR & $\begin{array}{l}\text { Effective Sea Level Rise: Baseline + impacts of sea-level } \\
\text { rise and land subsidence }\end{array}$ & $\mathrm{N}$ & $\mathrm{N}$ & $\mathrm{Y}+43 \mathrm{~cm}$ & $\mathrm{~N}$ \\
\hline S6-BAU & $\begin{array}{l}\text { Business as Usual: cumulative impacts of all drivers CC, } \\
\text { HP dams, SLR, and expansion of high-dyke } \\
\text { compartments }\end{array}$ & $\mathrm{Y}$ & $\mathrm{Y}$ & $\mathrm{Y}+43 \mathrm{~cm}$ & $\mathrm{Y}(2)$ \\
\hline S7-SD & $\begin{array}{l}\text { Sustainable Development: cumulative impacts of CC + } \\
\text { SLR, no further dams being built, and high-dyke flood } \\
\text { compartments opened providing flood storage. }\end{array}$ & $\mathrm{Y}$ & $\mathrm{N}$ & $\mathrm{Y}+43 \mathrm{~cm}$ & $\mathrm{Y}(1)$ \\
\hline a & \multicolumn{5}{|l|}{ No $(\mathrm{N}) / \mathrm{Yes}(\mathrm{Y})$} \\
\hline b & \multicolumn{5}{|c|}{ Y(1): open "high-dyke" compartments in the delta provinces An Giang and Dong Thap to provide flood storage. } \\
\hline c & \multicolumn{5}{|c|}{$\begin{array}{l}\text { Y(2): expand "high-dyke" compartments in An Giang and Dong Thap to maximize cultivation of triple rice crop in these } \\
\text { provinces. }\end{array}$} \\
\hline
\end{tabular}

Climate change (S4-CC): the discharge of the period 2036-2065 as projected by the MPI-ESM-LR (MPI) global simulation model under the Representative Concentration Pathway 4.5 (RCP 4.5) scenario was used as upstream boundary at Kratie.

Sea level rise (S5-SLR): this scenario investigates future changes in delta inundation under impacts of sea-level rise and deltaic land subsidence. Manh et al. (2015) suggested that the tidal level might increase $22-63 \mathrm{~cm}$ in the 2050s as consequence of effective sea-level rise. We used the mean of the suggested range $(+43 \mathrm{~cm})$ as change in the downstream boundary of the quasi-2D model.

Business as Usual (S6-BAU): cumulative impacts of all drivers were examined in the BAU scenario. This simulation considered the projected discharge of Kratie in 2036-2065, including all planned hydropower dams. The downstream boundary condition of the hydrodynamic model incorporated future effective sea-level rise, and delta infrastructure was modelled as in S3-DE.

Sustainable development (S7-SD): this scenario explores the possibility of countering the effects of climate change and effective sea-level rise on flood hazard with sustainable development measures. The planned hydropower development was excluded, because it is a non-sustainable development causing a series of problems on delta sediment equilibrium, river bank erosion, flood dynamics (Kondolf et al., 2014; Anthony et al., 2015; Pokhrel et al., 2018a; Pokhrel et al., 2018b; Schmitt et al., 2018; Hecht et al., 2019; Nhan and Cao, 2019). S7-SD is the combination of the scenarios S2-FR, S4-CC and S5-SLR. 


\subsection{Assessment of changes in flood hazard and damage}

We assessed impacts of the different drivers, as defined in the scenarios S1-HP to S7-SD, on the flood hazard in the VMD by comparing the simulation results with the baseline simulation. In each scenario, we computed the following flood hazard indicators: annual maximum water level (AMWLs), date of occurrence of AMWLs (DOCs), inundation extent, depth, and duration for each of the 30 simulated flood events. We first evaluated the mean changes between the reference and the future period. To investigate the potential changes in more detail, changes in AMWLs, flood extent, depth and duration were analysed for a dry year, a wet year, and a normal year. These events were defined using the 5\%,50\% and $95 \%$ quantiles of the annual flood volume $\left(F_{V}\right)$ at Kratie, computed by aggregating streamflow at Kratie from June 01 to November 30 . These quantiles are based on the 30 years discharge series of Kratie for each scenario. The flood events with $F_{V}$ closest to the quantile values are selected as representative for the dry, normal and wet year. $F_{V}$ is favoured over peak discharge because it better describes the severity of floods in the Mekong (MRC, 2005 ). In the next step, we quantified the changes in exposed areas (EA) of rice crops to inundation, and the estimated damage $(E D)$ in comparison to the baseline results.

\section{Data}

\subsection{Upstream boundary condition of the hydrodynamic model}

The upstream boundary of the hydrodynamic model is the gauge station Kratie in Cambodia (Fig. 1). The hydrodynamic model is driven by simulated daily discharge series of the Mekong River given in Hoang et al. (2018). The authors used the distributed, grid-based hydrological model VMod to simulate hydrology and flow dynamics of the Mekong River. The VMod model is grid-based, with varying cell sizes ranging from hundred metres up to several kilometres. For each time step and grid cell, the model first computes the climate forcing from the input meteorological data, followed by the computation of the vertical soil water balance. The runoff from each grid cell is routed through the entire river network to obtain discharge at the gauge Kratie, which is the terminus of the VMod model (Lauri et al., 2012).

Hoang et al. (2018) developed a VMod application covering the entire Mekong River Basin at 5x5 km spatial resolution, and simulated historical Mekong River flow using the WATCH climate data set (http://www.eu$\underline{\text { watch.org/) }}$ and the APHRODITE precipitation data set (http://www.chikyu.ac.jp/precip/old/index.html). The future Mekong flow was simulated using five GCMs, two emission scenarios (RCP 4.5 and RCP 8.5), and two basin development scenarios, comprised of hydropower dams development and irrigation expansion. Model calibration and validation were performed using observed discharge series at seven monitoring gauges in the Mekong mainstream from the most upstream at Chiang Sean to most downstream at Kratie. The model performed well against the observations, Nash-Sutcliffe efficiency coefficient of 0.67 for daily discharge, on average, for calibration (19811990) and validation (1991-2000). Räsänen et al. (2017) verified that the VMod model is capable of reproducing the flow alteration in the Lower Mekong Basin (LMB) resulting from the hydropower development in the Upper Mekong Basin (UMB). For a detailed description of the modelling setup, calibration, and validation of the VMod model, the readers are referred to Lauri et al. (2012); Hoang et al. (2016); Hoang et al. (2018).

Due to the large number of scenarios, given the different drivers and their combinations (see section 3.3), and the required simulation time, not all future scenarios of Hoang et al. (2018) were used to drive the hydrodynamic model. Out of the five GCMs, the MPI-ESM-LR (MPI) model was selected, because it is representative of the mean future 
hydrology of the Mekong predicted by VMod using all five GCMs (cf. to Fig. 4 in Hoang et al., 2016). Furthermore, only the RCP 4.5 climate scenario was used, based on the argument of Wang et al. (2017), that global temperature is unlikely to increase above $2.6^{\circ} \mathrm{C}$ by the end of the century due to the limited supply of fossil fuels. The RCP 4.5 closely matches this argument, as it assumes a peak in greenhouse gas emissions around 2040 with a subsequent decline, which is associated with a projected increase in global mean temperature of $1.1-2.6^{\circ} \mathrm{C}$ by the end of the $21^{\text {st }}$ century (IPCC, 2014). The impacts of irrigation expansion in the LMB were not considered in our assessments due to the minor alteration of the flood season flow at Kratie (less than $3 \%$ as depicted in Fig. 2 of Hoang et al. (2018)).

\subsection{Tidal level, elevation, land-use and other relevant data}

Hourly tidal level records from ten national tidal gauges along the coast of the VMD were obtained from the Southern Regional Hydro-Meteorology Center of Vietnam (SHRMC). These data served as lower boundary conditions for the hydraulic model. Locations, dimensions, and operation schemes of flood control structures in the VMD were acquired from the provincial Departments of Agriculture and Rural Development (DARDs). For the model setup and the derivation of inundation raster maps, a high-resolution $(5 \times 5 \mathrm{~m})$ LiDAR-based DEM of the VMD acquired from the Ministry of Environment and Natural Resources of Vietnam (MONRE) was used. LiDAR data was collected and processed between 2009 and 2010. Land-use data of the VMD was provided by the German Aerospace Centre (DLR). Leinenkugel et al. (2013) derived land-use map using the Moderate Resolution Imaging Spectroradiometer (MODIS) instrument aboard the Terra and Aqua satellites. The authors combined different MODIS products were combined to provide cloud free composites for the period 2001-2011, calculated the enhanced vegetation index (EVI), and performed the land-use classification. Triet et al. (2018) reclassified this original product to two raster images representing the summer-autumn crop, and autumn-winter crop to support flood damage calculation (cf. to Fig.3 in Triet et al., 2018).

\section{Results}

\subsection{Future projections of flood hazard and impacts of each driver}

\subsubsection{Average changes}

The average annual maximum water level (AMWL) and date of occurrence of AMWL (DOC) at 16 investigated gauges, computed as the mean of 30 flood events, are compared against the baseline simulation. The two-sided t-test is applied to mark the gauges and scenarios with significant changes in mean AMWLs or DOCs (Table 2 and 3 ).

Changes in average AMWLs are statistically significant in four scenarios, driven by (i) hydropower development (S1HP) by -1 to $-44 \mathrm{~cm}$, (ii) effective sea-level rise (S5-SLR) by $19-43 \mathrm{~cm}$, or (iii) a combination of these (S6-BAU and S7-SD) by 26-44 cm. The climate change (S4-CC) scenario projects an increase in mean AMWLs by 1-15 cm with the most substantial increases at gauges in the northern part of the VMD. However, these changes are not statistically significant at $p=0$.05. For the scenarios S2-FR and S3-DE with fewer or more high-dyke flood compartments in the VMD, respectively, minor changes in mean AMWLs in the range of $1-5 \mathrm{~cm}$ are obtained. For the mean DOCs, all but three scenarios project an insignificant shift. Similar to changes in mean AMWLs, significant alteration in mean DOCs are modelled in the scenarios S1-HP, S5-SLR and S6-BAU, with a smaller spatial distribution compared to changes in modelled AMWLs. The impact is limited to a few gauges in the middle region of the delta (e.g. Can Tho, My Thuan) delaying the occurrence of the AMWL by 10-20 days (Table 3). 
Table 2. Simulated annual maximum water level (AMWL) at main hydrological gauges in the VMD corresponding to the eight scenarios, computed as average of the 30-yr baseline and future periods. Statistically significant $(p \leq 0.05)$ changes compared to the baseline are marked in bold. The numbers in brackets present the changes compared to the baseline.

Unit: meter

\begin{tabular}{lclllllllll}
\hline Station name & & \multicolumn{7}{c}{ Modelling scenarios } \\
& $B L$ & $S 1-H P$ & $S 2-F R$ & $S 3-D E$ & $S 4-C C$ & $S 5-S L R$ & $S 6-B A U$ & $S 7-S D$ \\
\hline Tan Chau [1] & 3.41 & $\mathbf{3 . 0 3}(-0.38)$ & $3.39(-0.02)$ & $3.43(0.02)$ & $3.60(0.19)$ & $3.55(0.14)$ & $3.40(-0.01)$ & $\mathbf{3 . 6 9}(0.28)$ \\
Vam Nao [2] & 2.55 & $\mathbf{2 . 3 1}(-0.24)$ & $2.53(-0.02)$ & $2.56(0.01)$ & $2.67(0.12)$ & $\mathbf{2 . 7 6}(0.21)$ & $2.67(0.12)$ & $\mathbf{2 . 8 4}(0.29)$ \\
Cao Lanh [3] & 1.96 & $\mathbf{1 . 8 6}(-0.10)$ & 1.96 & $1.97(0.01)$ & $2.02(0.06)$ & $\mathbf{2 . 2 9}(0.33)$ & $\mathbf{2 . 2 6}(0.30)$ & $\mathbf{2 . 3 3}(0.37)$ \\
My Thuan [4] & 1.66 & $\mathbf{1 . 6 4}(-0.02)$ & 1.66 & 1.66 & $\mathbf{1 . 6 9}(0.03)$ & $\mathbf{2 . 0 5}(0.39)$ & $\mathbf{2 . 0 6}(0.40)$ & $\mathbf{2 . 0 8}(0.42)$ \\
Chau Doc [5] & 3.16 & $\mathbf{2 . 7 7}(-0.39)$ & $3.12(-0.04)$ & $3.17(0.01)$ & $3.34(0.18)$ & $3.30(0.14)$ & $3.14(-0.02)$ & $\mathbf{3 . 4 2}(0.26)$ \\
Long Xuyen [6] & 2.06 & $\mathbf{1 . 9 6}(-0.10)$ & 2.06 & $2.07(0.01)$ & $2.12(0.06)$ & $\mathbf{2 . 3 7}(0.31)$ & $\mathbf{2 . 3 4}(0.28)$ & $\mathbf{2 . 4 1}(0.35)$ \\
Can Tho [7] & 1.77 & $\mathbf{1 . 7 3}(-0.04)$ & 1.77 & 1.77 & $1.80(0.03)$ & $\mathbf{2 . 1 4}(0.37)$ & $\mathbf{2 . 1 3}(0.36)$ & $\mathbf{2 . 1 7}(0.40)$ \\
Dai Ngai [8] & 1.82 & $\mathbf{1 . 8 1}(-0.01)$ & 1.82 & 1.82 & $1.84(0.02)$ & $\mathbf{2 . 2 5}(0.43)$ & $\mathbf{2 . 2 5}(0.43)$ & $\mathbf{2 . 2 6}(0.44)$ \\
Xuan To [9] & 3.06 & $\mathbf{2 . 6 2}(-0.44)$ & $3.02(-0.04)$ & $3.07(0.01)$ & $3.28(0.22)$ & $3.21(0.15)$ & $3.03(-0.03)$ & $\mathbf{3 . 3 5}(0.29)$ \\
Tri Ton [10] & 1.86 & $\mathbf{1 . 5 8}(-0.28)$ & $1.85(-0.01)$ & $1.87(0.01)$ & $1.95(0.09)$ & $\mathbf{2 . 0 4}(0.18)$ & $1.94(0.08)$ & $\mathbf{2 . 1 3}(0.27)$ \\
Tan Hiep [11] & 1.16 & $\mathbf{1 . 0 5}(-0.11)$ & 1.16 & 1.16 & $1.20(0.04)$ & $\mathbf{1 . 3 9}(0.23)$ & $\mathbf{1 . 3 6}(0.20)$ & $\mathbf{1 . 4 4}(0.28)$ \\
Vi Thanh [12] & 0.74 & $0.73(-0.01)$ & 0.74 & 0.74 & $0.75(0.01)$ & $\mathbf{1 . 1 5}(0.41)$ & $\mathbf{1 . 1 5}(0.41)$ & $\mathbf{1 . 1 6}(0.42)$ \\
Moc Hoa [13] & 1.75 & $\mathbf{1 . 5 1}(-0.24)$ & 1.75 & $1.77(0.02)$ & $1.86(0.11)$ & $\mathbf{1 . 9 7}(0.22)$ & 1.86 & $(0.11)$ & $\mathbf{2 . 0 6}(0.31)$ \\
Hung Thanh [14] & 1.99 & $\mathbf{1 . 7 6}(-0.23)$ & 1.99 & $2.02(0.03)$ & $2.11(0.12)$ & $\mathbf{2 . 1 8}(0.19)$ & $2.09(0.10)$ & $\mathbf{2 . 2 7}(0.28)$ \\
Kien Binh [15] & 1.20 & $\mathbf{1 . 0 9}(-0.11)$ & $1.19(-0.01)$ & 1.20 & $1.25(0.05)$ & $\mathbf{1 . 4 9}(0.29)$ & $\mathbf{1 . 4 6}(0.26)$ & $\mathbf{1 . 5 4}(0.34)$ \\
Tan An [16] & 1.24 & $\mathbf{1 . 2 3}(-0.01)$ & 1.24 & 1.24 & $\mathbf{1 . 2 6}(0.02)$ & $\mathbf{1 . 6 3}(0.39)$ & $\mathbf{1 . 6 3}(0.39)$ & $\mathbf{1 . 6 5}(0.41)$ \\
\hline
\end{tabular}

${ }^{a}$ The numbers next to the station names denote their location (Figure 1, right panel).

Table 3. Simulated shifts in date of occurrence of annual maximum water level (DOC) at main hydrological gauges in the VMD. The DOCs are computed as computed as the mean of the 30-yr baseline and future periods.

Unit: day

\begin{tabular}{|c|c|c|c|c|c|c|c|c|}
\hline \multirow{2}{*}{ Station name } & \multicolumn{8}{|c|}{ Modelling scenarios } \\
\hline & $B L$ & $S 1-H P$ & $S 2-F R$ & $S 3-D E$ & $S 4-C C$ & S5-SLR & $S 6-B A U$ & $S 7-S D$ \\
\hline Tan Chau [1] ${ }^{\mathrm{a}}$ & Sep. 22 & +3 & $0^{\mathrm{b}}$ & 0 & +1 & +3 & +6 & +3 \\
\hline Vam Nao [2] & Sep. 29 & +6 & +1 & 0 & -2 & +2 & +9 & +1 \\
\hline Cao Lanh [3] & Oct. 11 & $+10^{\mathrm{c}}$ & +1 & -2 & -1 & +7 & +12 & +4 \\
\hline My Thuan [4] & Oct. 31 & +17 & 0 & 0 & +2 & +8 & +14 & +5 \\
\hline Chau Doc [5] & Sep. 26 & +2 & 0 & -2 & -2 & 0 & +4 & +1 \\
\hline Long Xuyen [6] & Oct. 09 & +6 & 0 & -2 & 0 & +1 & +10 & +2 \\
\hline Can Tho [7] & Oct. 23 & +11 & -1 & -2 & -1 & -1 & +9 & +2 \\
\hline Dai Ngai [8] & Oct. 29 & +1 & 0 & 0 & 0 & 0 & +2 & +1 \\
\hline Xuan To [9] & Sep. 27 & +2 & 0 & -2 & -1 & 0 & +2 & +1 \\
\hline Tri Ton [10] & Sep. 30 & +3 & 0 & -1 & +2 & +2 & +7 & +5 \\
\hline Tan Hiep [11] & Oct. 07 & +8 & +3 & 0 & +2 & +8 & +14 & +9 \\
\hline Vi Thanh [12] & Nov. 03 & +13 & 0 & 0 & 0 & +9 & +16 & +5 \\
\hline Moc Hoa [13] & Oct. 05 & -1 & 0 & 0 & +2 & +3 & +5 & +3 \\
\hline Hung Thanh [14] & Oct. 07 & +1 & +1 & -2 & +2 & 0 & +6 & +3 \\
\hline Kien Binh [15] & Oct. 14 & 0 & -1 & -1 & -1 & +3 & +15 & +6 \\
\hline Tan An [16] & Nov. 01 & +20 & +1 & -1 & +2 & +13 & +17 & +7 \\
\hline
\end{tabular}

${ }^{a}$ The numbers next to the station names denote their location (Figure 1, right panel).

${ }^{\mathrm{b}}$ No difference in the DOC compared to baseline

c Statistically significant $(p<0.05)$ changes compared to the baseline are marked in bold. 
Figure 3 summarises the modelled flood extent of the 30 flood events for the eight scenarios. The most significant increases in flood extent are found in the scenarios simulating the impacts of effective sea-level rise, i.e. S5-SLR, S6BAU, and S7-SD. Mean flood extents increase by 35\%, $28 \%$ and 43\%, respectively, in comparison to the baseline scenario with $22500 \mathrm{~km}^{2}$ mean extent. S2-FR and S4-CC (floodplain restoration and climate change) project only slightly larger flood extent of 3\%, while hydropower development (S1-HP) and expansion of high-dyke flood compartments (S3-DE) reduce the flooded area by $7 \%$ and 3\%, respectively.

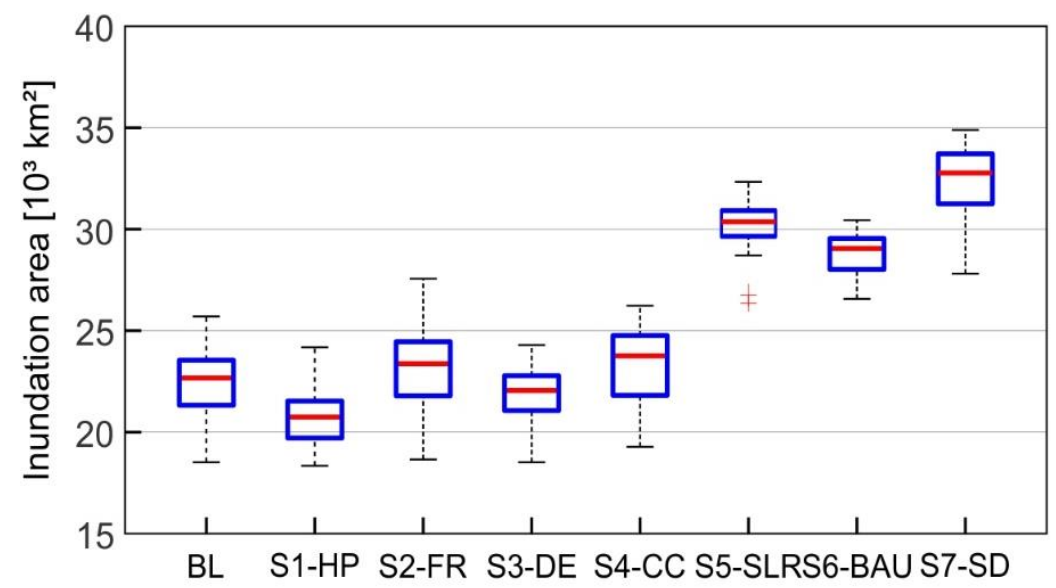

Figure 3. Boxplot of the simulated maximum inundation extent for 30 flood events for the eight scenarios.

\subsubsection{Changes for a dry, normal and wet year}

\section{Impact of hydropower development}

The hydropower development scenario shows considerable effects on the flood hydraulics in the Mekong Delta for the dry, normal and wet year. The hydropower dams reduce the flood volume at Kratie during the rising and high flood phase (July-September) $7 \%$ in the dry year, and by $15 \%$ in the normal and wet years. Compared to the baseline, hydropower development causes a decrease in AMWLs of $14 \%$ at maximum in a wet year, and up to $27 \%$ in a normal or dry year. Eight of the 16 gauges show a decrease in AMWLs of more than 5\% in the dry year. In the normal and wet years, this decrease in AMWL is observed at even 12 stations (Fig. 4 a-c). The largest decreases are found in the northern part of the VMD, where AMWLs reduce by 30-70 cm (13-30\%) at Chau Doc at the Vietnam-Cambodia border. The magnitude of changes sharply decreases -7 to $-16 \mathrm{~cm}(4-8 \%)$ at Long Xuyen about $60 \mathrm{~km}$ downstream of Chau Doc, and below $-6 \mathrm{~cm}(-5 \%)$ at Can Tho in the middle of the delta. Inundation extent also decreases by $8 \%$ in the normal year (in relation to $23,000 \mathrm{~km}^{2}$ or $57 \%$ of the delta area), by $5 \%$ in the wet year (in relation to 24,500 $\mathrm{km}^{2}, 61 \%$ ), and by $1 \%$ in the dry year (in relation to $19,000 \mathrm{~km}^{2}, 47 \%$ ) (Fig. $5 \mathrm{a}-\mathrm{c}$ ). Hydropower dams also shorten the inundation duration. The inundation duration of more than three months in the baseline scenario decreases by $3 \%$ in the normal year, and 5\% the wet year (Fig. 6 and Table S4 in the Supplement). For the dry year, no changes are modelled.

\section{Impact of local water infrastructure}

The local water infrastructure scenarios, floodplain restoration S2-FR and expansion of high-dyke compartments S3-DE, cause relative minor changes. Both scenarios show no changes in AMWLs compared to the baseline in the dry year (Fig.4 d, g). Small decreases of less than 5\% (1-5 cm) in AMWLs are modelled for S2-FR in the normal and wet years (Fig. 4 e, f). A similar magnitude, but opposite sign is projected for S3-DE (Fig. 4 h, i). Flood extent alters by $\pm 1.5 \%$ in the normal year, and by $\pm 3 \%$ in the wet year; positive changes are computed for S2-FR, and negative 
changes for S3-DE. Changes in inundation depth (above $0.5 \mathrm{~m}$ ) and inundation duration (above 2 months) occur at the high-dyke flood compartments which are opened to intake floodwater in S2-FR runs (blue pixels in Fig. 5 d-f), or at low-dyke compartments converted to high-dykes in S3-DE (red pixels in Fig.5 g-i). The effects are thus rather limited and confined to the areas where the changes in water infrastructure were defined (deep submergence areas in the northern part of the VMD). The impacts on downstream areas in terms of AMWLs, flood extent and duration are small (below $2 \mathrm{~cm}$ in AMWL).

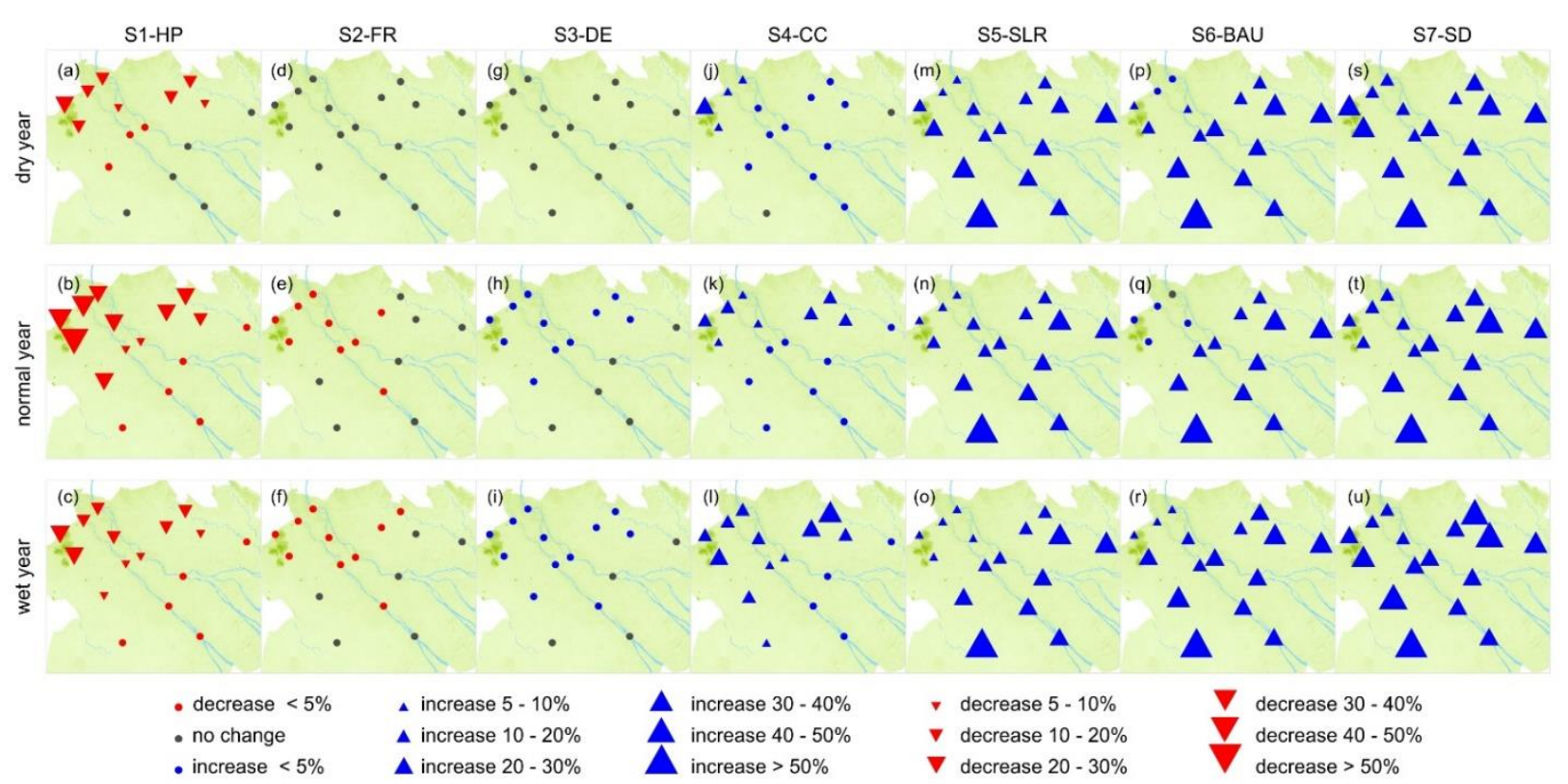

Figure 4. Changes in annual maximum water level at main gauges in the VMD relative to the baseline (BL) corresponding to a dry, normal and wet years. See Tables S1 to S3 in the Supplement for the absolute values.

\section{Impact of climate change}

For the climate change scenarios S4-CC, the spatial patterns of changes are similar to the impacts of hydropower development, i.e. confined to the border of Vietnam and Cambodia and the centre of the VMD. Compared to the baseline, climate change increases the AMWLs by 20-35 cm (10-15\%) at Chau Doc, 3-15 cm (2-8\%) at Long Xuyen, and 2-7 cm (less than 5\%) at Can Tho, with higher changes computed in the wet year (Fig. $4 \mathrm{j}-1$ and Table S1-S3 in the supplement). Flood extent increases by $1 \%, 3 \%$ and $7 \%$ in the dry year, normal year and wet year, respectively (Fig. 6 and Table S4 in the supplement); and inundation depth increases by 10-40 cm (Fig. 5 j-1). The impacts of climate change on delta flood hazard approximately offset the changes caused by hydropower development (S1-HP) except for the normal year, particularly the inundation depths. For inundation duration, the area inundated for more than two months increases by $1 \%$ in the dry and normal years, and by $9 \%$ in the wet year (Fig. 6 and Table S4 in the supplement).

\section{Impact of effective sea-level rise}

The largest changes in AMWLs are obtained in the S5-SLR scenario, showing the impacts of effective sea-level rise (sea-level rise plus deltaic land subsidence). The AMWLs increased by $13-40 \mathrm{~cm}(5-60 \%)$. Increases are found even at gauges in the deep submergence area of the VMD, with an increase of $13 \mathrm{~cm}(6 \%)$ in the normal and wet years, and $22 \mathrm{~cm}(10 \%)$ in the dry year in Chau Doc. However, the largest change in AMWLs is modelled in the middle and coastal regions of the delta (Fig. 4 m-o). For example, at Can Tho AMWLs increase by 20-25\% for S5- 
SLR, five times higher than the projected change due to hydropower development (S1-HP) or climate change (S4CC). In addition to increasing AMWLs in the main channels, sea-level rise led to submergence of additional flood compartments. Therefore, the inundation extent increases by $19-21 \%$, from $47 \%, 56 \%$ and $60 \%$ of delta land area computed for the baseline to $67 \%, 76 \%$ and $81 \%$ for dry, normal and wet years, respectively (Fig. 6). Inundation depth increases by $0.1-0.5 \mathrm{~m}$ (Fig. $5 \mathrm{~m}-\mathrm{o}$ ), together with a significant shift from short (less than one month) to longer inundation periods (above three months) (Fig. 6 and Table S4 in the supplement).

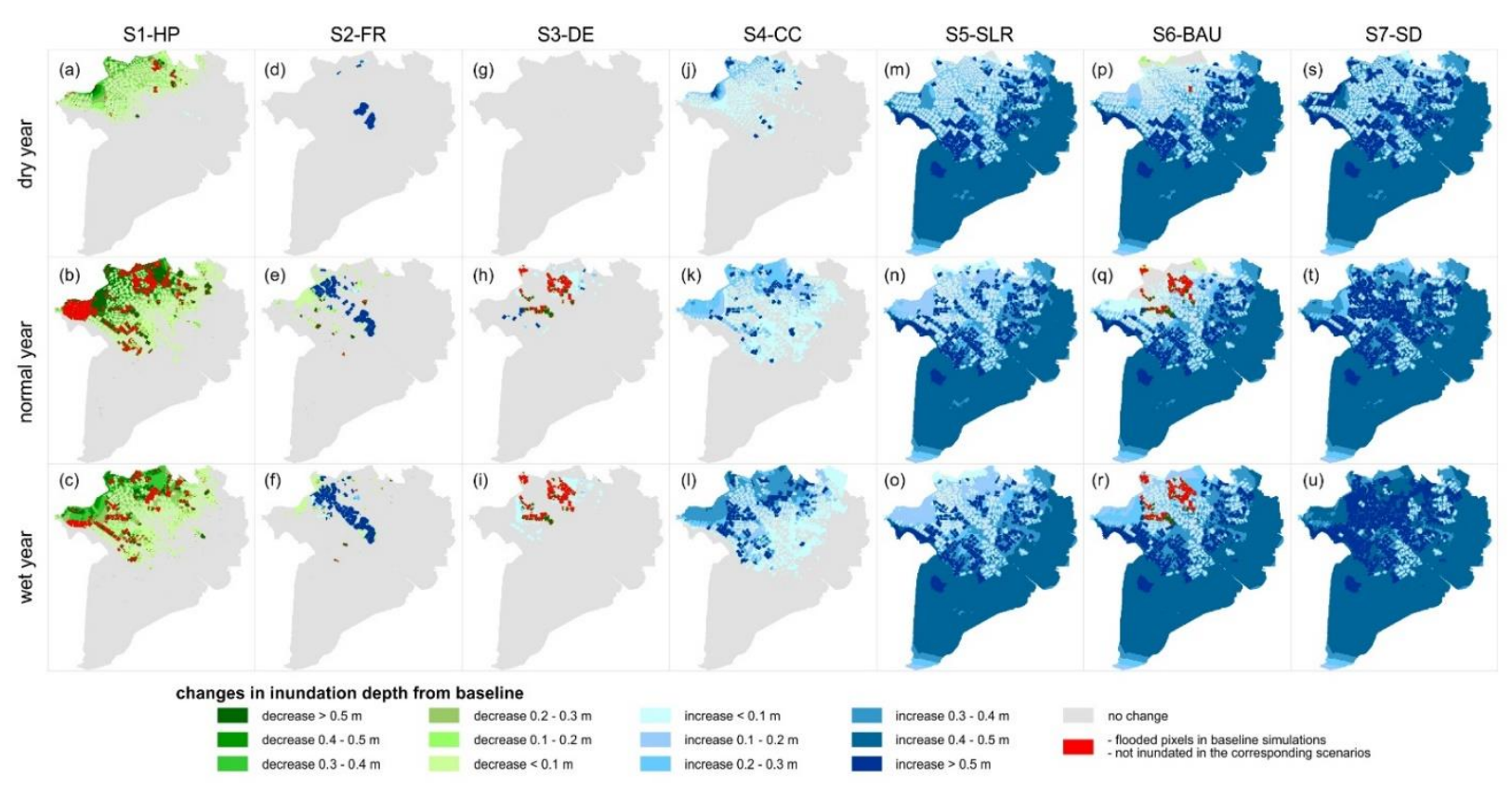

Figure 5. Changes in inundation extent and depth relative to the baseline $(B L)$ corresponding to a dry, normal and wet years.

(a) dry year

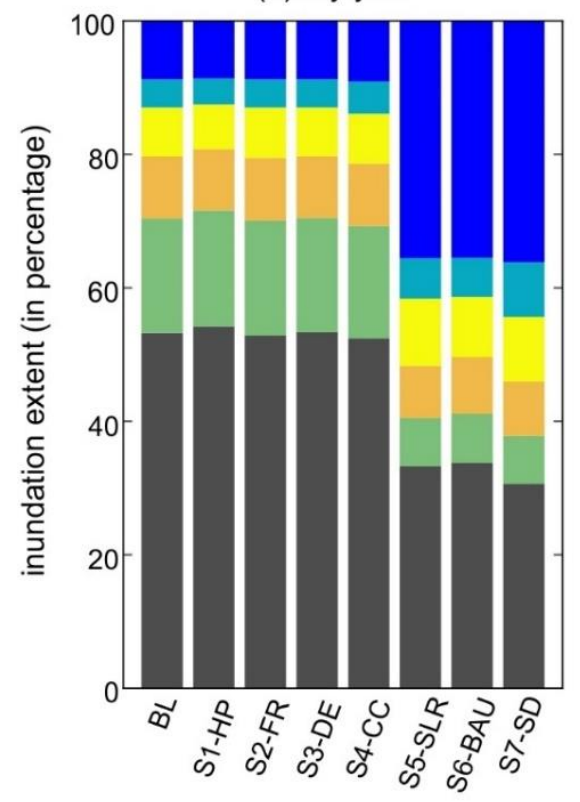

(b) normal year

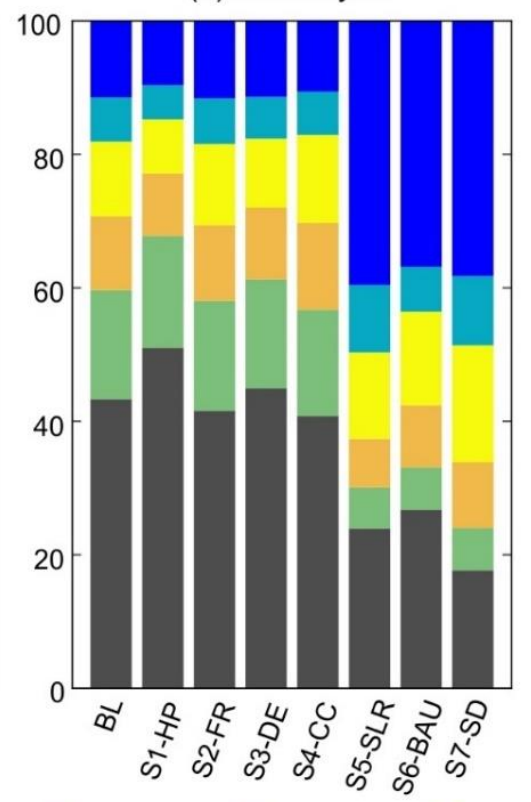

(c) wet year

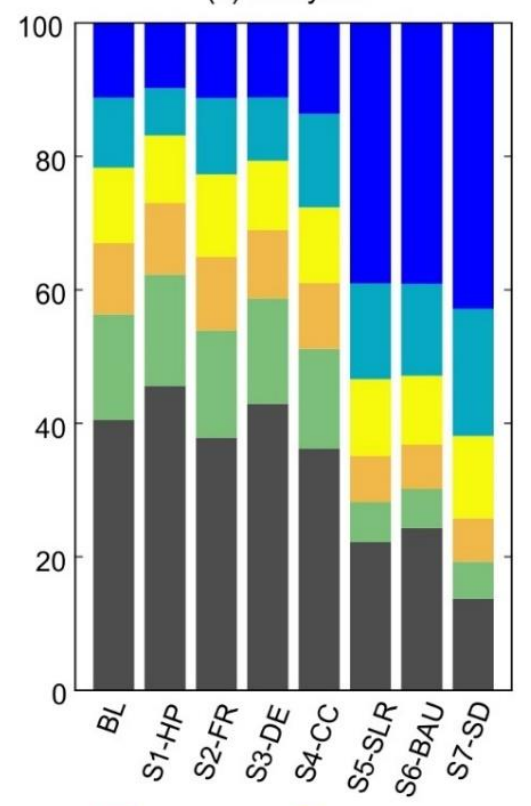

inundation duration:

no inundation

1 1 month $\square<2$ month $\square<3$ month

$<4$ month

$>4$ month

Figure 6. Inundated extent differentiated according to duration (number of months flooded) by the different scenarios in dry year (a), normal year (b), and wet year (c). See Table S4 in the Supplement for tabulated data. 


\section{Cumulative impact of climate change, hydropower, sea-level rise, and delta infrastructure}

The cumulative impact of multiple drivers is examined in two scenarios, namely the business-as-usual (S6-BAU), and the sustainable-development (S7-SD) scenarios. S6-BAU is a combination of four drivers: S1-HP (hydropower development), S3-DE (dyke expansion), S4-CC (climate change), and S5-SLR (effective sea-level rise). In this scenario, the hydropower development partially compensates the higher AMWLs caused by the other drivers, most notably at gauges in the northern part of the delta. At Chau Doc, an increase in AMWL by $10 \mathrm{~cm}$ is simulated for S6BAU for the dry year, and $17 \mathrm{~cm}$ for the wet year, which is about half of the simulated change for S4-CC and S5SLR (20-35 cm). Due to the comparatively high impact of hydropower development on AMWLs in normal years (about the same magnitude as for wet years, cf. section 4.1.1), AMWL at Chau Doc changes by only $2 \mathrm{~cm}$ in S6-BAU in a normal year. From the centre of the delta to the coastal region, an increase of $30-40 \mathrm{~cm}(15-25 \%)$ relative to the baseline is simulated (Fig. 4 p-r); this range is similar to the S5-SLR scenario, i.e. effective sea-level rise alone. The inundated area of S6-BAU is marginally smaller (1-3\%) than the inundated area simulated in S5-SLR (Fig. 6 and Table S4 in supplement). This is mainly a combined effect of the similar impact of effective sea-level rise on inundation in the central and coastal parts of the delta in S5-SLR and S6-BAU, and the blocking of floodplain inundation in the deep submergence zone by the development of high dyke compartments just as in S3-DE (Fig. 5 pr).

Contrary to S6-BAU, the S7-SD scenario results in overall increases in AMWLs, flood extent, flood depth and duration relative to the baseline (Fig. 4 s-u, Fig. 5 s-u, and Fig. 6). In this scenario, about 70\% and 90\% of the VMD land area are inundated in the dry and wet year, respectively. The simulated flood extent increases by $22 \%$ in the dry year, $25 \%$ in the normal year and $26 \%$ in the wet year. The AMWLs at all gauges increase by $30-40 \mathrm{~cm}$ (Fig. $4 \mathrm{~s}-\mathrm{u}$ ). Moreover, the regions inundated longer than three months increase by $30 \%$ in the dry and normal years, and up to $40 \%$ in the wet year (Fig. 6).

\subsection{Impacts of flood hazard changes on agriculture}

Figure 7 summarises exposed areas $(E A)$ and estimated damage $(E D)$ of paddy rice plantation for the eight scenarios (see Table S5 of the supplement for tabulated data). The calculation of $E A$ and $E D$ is limited to the floodprone area of the VMD (marked in Fig. 1). The expansion of high-dyke compartments in S3-DE and S6-BAU allows the cultivation of one extra rice crop per year, by changing the cropping system from double to triple season rice. For the baseline, the inundated rice farming areas $(E A)$ in the dry, normal and wet years amount to 2,500, 11,000 and 60,500 hectares, respectively; and the $E D$ is computed to 2.0, 9.0 and 54.0 US\$ millions.

S1-HP (hydropower development) and S2-FR (floodplain restoration) simulate a decrease in EA and ED. For S1-HP, $E A$ is reduced by $17 \%, 66 \%$ and $88 \%$ in dry, normal and wet years; this translates into a reduction in $E D$ of $19 \%, 66 \%$ and $63 \%$. For S2-FR, EA and $E D$ are reduced by $7 \%$ in the wet year only. All other scenarios project an increase in $E A$ and $E D$. Similar to S2-FR, changes in $E A$ and $E D$ are found only for the wet year for S3-DE, with 64000 hectares and 57.0 US\$ millions (an increase of 5\% relative to the baseline). The climate change scenario (S4-CC) projects an increase of $E A$ by $38 \%, 3 \%$ and $71 \%$ in dry, normal and wet years, respectively; these values are equivalent to an increase of $33 \%, 11 \%$ and $90 \%$ in $E D$. Much larger increases of $E A$ and $E D$ are obtained for the remaining scenarios S5-SLR, S6-BAU and S7-SD, amounting to 15-18 times the baseline $E A$ in the dry year (39,000-46,500 ha), 5-7 times in the normal year (49,000-70,500 ha), and 2-4 times in the wet year (110,000-249,000 ha). The corresponding 
changes in ED are computed as 12-14 times (28.0-33.0 US\$ millions), 4-6 times (36.0-52.0 US\$ millions), and 2-4 times (82.0-223.0 US\$ millions) for the dry, normal and wet years.
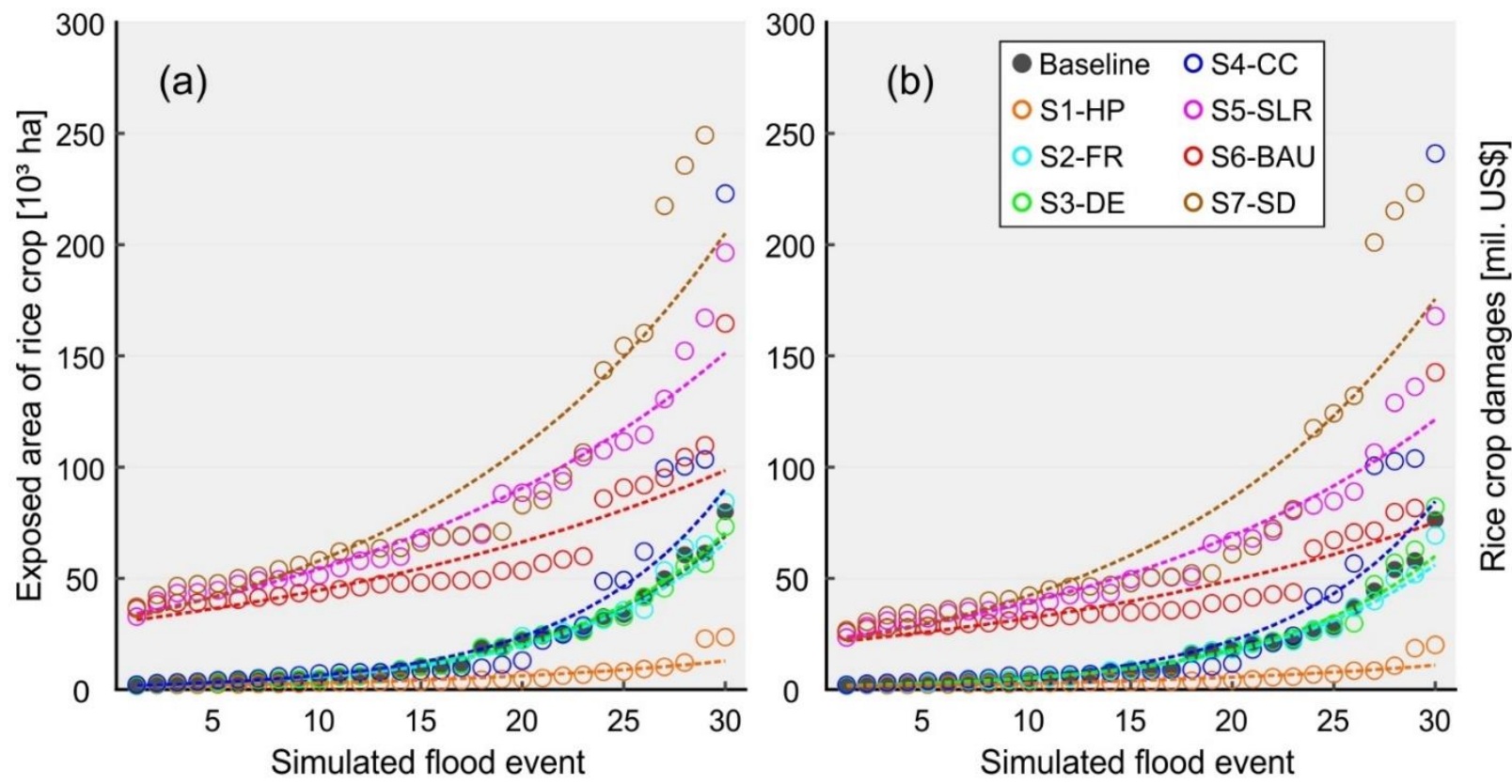

Figure 7. Exposed areas (EA) (a) and flood damage (ED) (b) to rice crop for 240 flood events differentiated in the eight scenarios.

\section{Discussion}

\subsection{Future projections of delta flood dynamics}

Our scenario simulations revealed an increase in flood hazard and affected agricultural area in the VMD by 20362065 as the result of the cumulative impacts of climate change, anthropogenic development and effective sea-level rise. We estimated an increase of flood extent by 20-27\% compared to the baseline period 1971-2000 under climate change and effective sea-level rise (S6-BAU, S7-SD: RCP 4.5, plus $43 \mathrm{~cm}$ in tidal level). A large share of the additional inundated areas shift from non-flooded, or short period inundation (less than one month) to longer duration inundation (3-4 months, Fig. 6). Our results demonstrate the dominant impact of sea-level rise and land subsidence on future delta inundation (shown in Fig. 5 m-o, and in Fig. 6; (e.g. Le et al., 2007; Van et al., 2012; Toan, 2014; Dang et al., 2018), with climate change acting as a second-order effect (Fig. 6 j-1). This statement holds true for many other world coastal deltas, e.g. Ganges-Brahmaputra, Irrawaddy (Auerbach et al., 2015; Tessler et al., 2015). In line with the expansion of long duration inundation areas, the estimated flood damage to agricultural areas $(E D)$ increased by 25-170 US\$ million relative to the baseline (Fig. 7b). The estimation of damage to agricultural areas was limited to the flood-prone areas, amounting to about $50 \%$ of the delta land area, and to paddy rice cultivation, as damage models for other crops are lacking (Triet et al., 2018). Thus, the overall flood damage to delta agriculture production will be significantly higher. Even though these crops, e.g. orchard farms, shrimp ponds, are not comparable to paddy rice in terms of plantation area, their economic values are considerably higher.

The modelled results suggest hydropower development in the Mekong Basin (S1-HP) is likely to mitigate the increasing climate change impacts on inundation in the flood-prone area (Fig. 1b) of the VMD. However, this area already experiences deep and long inundation, and agriculture and society are well adapted to this annual flood pulse (Howie, 2012). Therefore, flood mitigating benefit of hydropower dams is unlikely to compensate for their suggested 
negative impacts. The scenario examining only the impacts of hydropower dams (S1-HP) suggests that in normal flood events part of the delta flood-prone region will not be flooded anymore; distressing livelihoods of local residents. More important, hydropower dams substantially reduce sediment load to the Mekong Delta (Kummu et al., 2010; Kondolf et al., 2014), and sedimentation in the delta (Anthony et al., 2015; Manh et al., 2015), thus exacerbating coastal erosion, deltaic land subsidence, riverbank collapse (Van Binh et al., 2019); and subsequently increasing floodplain inundation. Besides, the scenario examining only the impacts of hydropower dams (S1-HP) suggests that in normal flood events part of the delta flood-prone region will not be flooded anymore.

The floodplain restoration scenario S2-FR analysed the impact of the high-dyke system in the VMD, constructed mainly after the disastrous flood in 2000. Our simulations confirmed the previous studies of Triet et al. (2017) and Dang et al. (2018): high-dyke development shifted flood hazard to neighbouring areas and caused higher water levels locally. However, the impacts of high-dyke development are less severe than changes caused by the other drivers. Note that S2-FR did not consider removing the entire the dyke system in the northern provinces of the VMD An Giang and Dong Thap (Fig. 1b), but assumed an opening of the sluice gates at high-dyke compartments after August 31 (harvest time of the second crop) in order to store floodwater during the high flood phase. From a hydraulic point of view, the high-dyke compartments operate almost as low-dyke compartments in this case, but still offer flood protection for the population living on the high-dykes. It is argued in Tran et al., 2018b that complete removal of all dyke systems in these two provinces could reduce the flood hazard in the centre and coastal regions of the VMD. We have not explored this scenario, because complete removal of the current dyke system in the VMD is unrealistic. Many delta inhabitants settle on high-dykes after moving from the floodplains to the elevated areas for flood protection (Reis, 2007). Resettlement of almost the whole population in the deep submergence zone and the demolishing of thousands of kilometres of dykes is not feasible. On the contrary, the controlled flooding of high-dyke compartments during extreme floods (S2-FR) has multiple benefits: (i) use as an emergency flood management option to lower the flood hazard for the central part of the delta including its economic hub Can Tho; a reduced water level of a few centimetres can have a very beneficial effect on flooding in the low terrain of the VMD (Apel et al., 2016), (ii) reduced damage to rice crop (Fig. 7), and (iii) controlled replenishment of sediment and nutrients to flooded compartments (e.g. Manh et al., 2014). However, this operation scheme requires a reliable flood forecast by July-early August, i.e. prior to the plantation of the third rice crop during the flood season, in order to reduce economic damages to farmers, whose land is flooded in case of opening the sluice gates. It should also be noted that the reduction in flood water levels is low in the range of $1-5 \mathrm{~cm}$.

The small changes in AMWLs and inundation extent by an expansion of the high-dyke system in S3-DE can be attributed to the fact that in the baseline runs the high-dyke system already covered two-third of An Giang and onehalf of Dong Thap provinces (Fig1.b). Although the flood extent and agriculture damage in S3-DE are comparable to the baseline, the further expansion of high-dykes and the associated introduction of a third rice crop in these newly protected floodplain compartments led to a potential increase in $E A$ and $E D$ of rice cropping areas. Which can be imminent in case of dyke breach or extreme floods exceeding the design level of the high-dykes. In addition, a highdyke expansion would result in higher channel flow velocities, thus exacerbating the risk of channel erosion (Kondolf et al., 2018). Even more important, separating floodplains and channels would reduce floodplain sedimentation delivered by the floods, resulting in higher costs for rice cultivation and reduced crop yield. Tran et al. (2018a) suggested that after 10-15 years the benefit for farmers from cultivation an extra crop is likely to be zero compared to growing only two rice crops due to the increase production costs. Reducing floodplain sedimentation would also further increase the effective sea-level rise and exposure of rice crops to inundation (Manh et al., 2015). 
From a flood management point of view, the major concern for the future is the increase in inundation duration. Most of the newly or prolonged submerged areas in scenarios S5-SLR, S6-BAU, and S7-SD are located in the coastal region of the VMD. In these regions, the waterworks for flood control are less developed compared to the northern provinces. The shift in inundation duration from 1-2 to 3-4 months means that either the agriculture system in these coastal provinces has to change to match the new emerging condition (e.g. alter cropping calendar or land-use), or substantial infrastructure investments are required to maintain agricultural production (e.g. new dyke systems, embankments, sluice gates, pumping stations). The results thus stress the necessity to develop a flood adaptation and management plan for VMD focussing on tidal backwater induced inundation hazard. The issue has been already observed in many major cities of the VMD, including the largest city Can Tho (Takagi et al., 2014). These control structures are also required to address the higher saline intrusion in the dry season associated with higher tidal levels (Toan, 2014; Smajgl et al., 2015).

\subsection{Uncertainties, limitations and directions of future studies}

Our results are subject to limitations and uncertainties related to (i) the limited number of scenarios for climate change projections for the Mekong river runoff, for the effective sea-level rise, and for the hydropower development in the basin, and (ii) the structure and parameterization of the hydrological and hydrodynamic models. Hoang et al. (2018) generated ten projections of Mekong streamflow using five GCMs in combination with two emission scenarios (RCP 4.5 and RCP 8.5). The range of the projected streamflow narrowed for these projections compared to earlier studies (e.g. Lauri et al., 2012). Due to the computer runtime of the hydraulic model, we used only one projection (RCP 4.5, with MPI global circulation model). However, because the MPI-RCP4.5 scenario resembles the ensemble mean of streamflow of Hoang et al. (2018), the simulated changes in flood hazard and potential damages can be regarded as the most likely projection. A similar argument holds for the selected effective sea-level rise scenario, which represents the mean value of the suggested range in Manh et al. (2015). Our scenarios thus represent the most likely future pathways under current knowledge without addressing the uncertainty associated with the future climate and sea-level rise development (Manh et al., 2015).

We also acknowledge the uncertainty in the scale of hydropower development in the Mekong Basin. Our analysis considered rather the extreme case of all planned dams to be built and operated. The prospect of all these dams to be constructed and operated for power generation purpose only by 2036-2065 is subject to political and economic development, thus the flood buffering capacity of hydropower development might be considerably smaller.

Another source of uncertainties stems from the hydrological model VMod to simulate streamflow in the Mekong Basin. The model has been extensively updated and calibrated by Hoang et al. (2018), achieving good performance on simulated discharge. However, the model performance with regard to flood volume is not yet defined. It could be argued that a good performance for daily flow should yield acceptable performance for flood volume, but we suggest to determine the model performance also for flood volume as the second parameter in a multi-objective calibration.

The flood propagation model contains some model structure limitations. The model network for the coastal regions is less comprehensive compared to other parts of the delta (e.g. the flood-prone area). Limited data availability resulted in a rather coarse channel network for this part of the model domain. The same holds true for water infrastructures like dykes and sluice gates. Further, monitoring data (water level, discharge series) for model calibration are mainly available for the main rivers. This results in some unquantifiable uncertainty in the discharge and water level simulations in the more remote areas. The model setup for the Cambodian part of the delta is based on a coarser DEM compared to the VMD, and also the information on the channel network and bathymetry are likely 
outdated. The Cambodian delta has witnessed quite some structural changes in the last decade and is expected to continuously change in the future following the country's socio-economic development (Kondolf et al., 2018). This might have an impact on the propagation of the Mekong flood pulse to the VMD. Further uncertainty may stem from the transformation of 1-D water levels to 2-D inundation maps, influencing the flood-affected area. A detailed discussion on the limitations of this top-down approach on flood damage and risk to rice crop in the VMD can be found in Triet et al. (2018). Despite these limitations of the flood propagation model, a number of studies using the same or modified model versions (e.g. Manh et al., 2015; Triet et al., 2017; Dang et al., 2018; Tran et al., 2018b) demonstrated that it provides valid results, particularly on the large, delta-wide scale of this application.

\section{Conclusions}

We implemented a comprehensive set of hydrodynamic modelling scenarios to quantify future projections of flood hazard and potential damage to rice cropping in the Vietnamese Mekong Delta (VMD) under climate change and anthropogenic stresses, namely hydropower dam development in the Mekong Basin, and high-dyke extension in the VMD. Results from our assessment suggest the combination of sea-level rise and land subsidence dominates the increase in future delta flood hazard and damage to rice cultivation, and hydropower development could counteract the changes in delta inundation dynamics driven by climate change. High-dyke development in the VMD has the smallest and locally confined impact on flood hazard. This can be, however, utilized for emergency flood management, because also small reductions in water levels can make a difference in inundation in this low-lying terrain. Opening of high-dyke compartments has immediate effect on flood propagation in the delta providing that a reliable flood forecast is available.

The assumptions and limitations of the study do not influence the main insights, that mitigation actions are urgently required reduce land subsidence in the delta, which is actually outpacing climate change induced sea-level rise (Minderhoud et al., 2017). A better control and reduction of groundwater abstraction would be the first and immediate step in this direction. Furthermore, long term strategic planning of flood management should have a particular focus on tidal influenced flood regions of the delta, and should encompass hard measures like flood protection infrastructure, but also non-structural one as changes in land use, cropping calendar combined with a reliable early flood forecast.

\section{Declaration of competing interest}

The authors declare no competing interests that could influence the work reported in this paper.

\section{Acknowledgement}

The work leading to this publication was supported by the German Academic Exchange Service (DAAD) - NaWaM Programme (grant No. 91549379). The authors would like to thank Mr. Pham The Vinh, and various colleagues at the Southern Institute of Water Resources Research for their support to this study, providing the DEM and survey data. Additionally MK received funding from Academy of Finland funded project WATVUL (grant No. 317320) and European Research Council (ERC) under the European Union's Horizon 2020 research and innovation programme (grant agreement No. 819202). 


\section{Author contributions}

Conceptualization, Methodology: N.V.K.T., N.V.D., L.P.H. and D.D.T. Resources: N.V.K.T. and L.P.H. Software: N.V.K.T. and N.V.D. Visualization: N.V.K.T, L.P.H., D.D.T., N.L.D. and T.T.A. N.V.K.T. drafted the paper, which was then discussed and edited by all co-authors.

\section{References}

Anthony, E. J., Brunier, G., Besset, M., Goichot, M., Dussouillez, P., and Nguyen, V. L.: Linking rapid erosion of the Mekong River delta to human activities, Scientific reports, 5, srep14745, 2015.

Apel, H., Martínez Trepat, O., Hung, N. N., Chinh, D. T., Merz, B., and Dung, N. V.: Combined fluvial and pluvial urban flood hazard analysis: concept development and application to Can Tho city, Mekong Delta, Vietnam, Nat. Hazards Earth Syst. Sci., 16, 941-961, 10.5194/nhess-16-941-2016, 2016.

Arias, M. E., Cochrane, T. A., Kummu, M., Lauri, H., Holtgrieve, G. W., Koponen, J., and Piman, T.: Impacts of hydropower and climate change on drivers of ecological productivity of Southeast Asia's most important wetland, Ecological modelling, 272, $252-263,2014$

Auerbach, L. W., Goodbred Jr, S. L., Mondal, D. R., Wilson, C. A., Ahmed, K. R., Roy, K., Steckler, M. S., Small, C., Gilligan, J. M., and Ackerly, B. A.: Flood risk of natural and embanked landscapes on the Ganges-Brahmaputra tidal delta plain, Nature Climate Change, 5, 153-157, 10.1038/nclimate2472, 2015.

Dang, T. D., Cochrane, T. A., Arias, M. E., and Tri, V. P. D.: Future hydrological alterations in the Mekong Delta under the impact of water resources development, land subsidence and sea level rise, Journal of Hydrology: Regional Studies, 15, 119-133, https://doi.org/10.1016/j.ejrh.2017.12.002, 2018.

Deltares: Mekong Delta Plan, Long-term vision and strategy for a safe, prosperous and sustainable delta, in, 126, 2013.

Dung, N. V., Merz, B., Bárdossy, A., Thang, T. D., and Apel, H.: Multi-objective automatic calibration of hydrodynamic models utilizing inundation maps and gauge data, Hydrology and Earth System Sciences, 15, 1339-1354, 2011.

Erban, L. E., Gorelick, S. M., and Zebker, H. A.: Groundwater extraction, land subsidence, and sea-level rise in the Mekong Delta, Vietnam, Environmental Research Letters, 9, 084010, 10.1088/1748-9326/9/8/084010, 2014.

Ericson, J. P., Vörösmarty, C. J., Dingman, S. L., Ward, L. G., and Meybeck, M.: Effective sea-level rise and deltas: Causes of change and human dimension implications, Global and Planetary Change, 50, 63-82, https://doi.org/10.1016/i.gloplacha.2005.07.004, 2006.

GSO: Statistical handbook of Vietnam 2015, General statistics office of Viet Nam, 2015.

Hackney, C. R., Darby, S. E., Parsons, D. R., Leyland, J., Best, J. L., Aalto, R., Nicholas, A. P., and Houseago, R. C.: River bank instability from unsustainable sand mining in the lower Mekong River, Nature Sustainability, 10.1038/s41893-019-0455-3, 2020 .

Hecht, J. S., Lacombe, G., Arias, M. E., Dang, T. D., and Piman, T.: Hydropower dams of the Mekong River basin: A review of their hydrological impacts, Journal of Hydrology, 568, 285-300, https://doi.org/10.1016/j.jhydrol.2018.10.045, 2019.

Hirabayashi, Y., Mahendran, R., Koirala, S., Konoshima, L., Yamazaki, D., Watanabe, S., Kim, H., and Kanae, S.: Global flood risk under climate change, Nature Climate Change, 3, 816, 10.1038/nclimate1911

https://www.nature.com/articles/nclimate1911\#supplementary-information, 2013.

Hoang, L. P., van Vliet, M. T. H., Kummu, M., Lauri, H., Koponen, J., Supit, I., Leemans, R., Kabat, P., and Ludwig, F.: The Mekong's future flows under multiple drivers: How climate change, hydropower developments and irrigation expansions drive hydrological changes, Science of The Total Environment, https://doi.org/10.1016/j.scitotenv.2018.08.160, 2018.

Hoang, P., Lauri, P., Kummu, M., Koponen, J., Van Vliet, M. T., Supit, I., Leemans, H., Kabat, P., and Ludwig, F.: Mekong River flow and hydrological extremes under climate change, Hydrology and Earth System Sciences Discussions, 20, 3027-3041, 2016.

Hoanh, C. T. J., Kittipong, Lacombe, G., and Srinetr, V.: Impacts of climate change and development on Mekong flow regime. First assessment - 2009, MRC Technical Paper No. 29. Mekong River Commission. Vientiane, Lao PDR, 2010.

Howie, C.: Dike building and agricultural transformation in the Mekong Delta, Vietnam: dilemmas in water management, Vietecology, Singapore GroupAt: Nanyang University, Singapore, Singapore, 2012.

Hung, N. N., Delgado, J. M., Tri, V. K., Hung, L. M., Merz, B., Bárdossy, A., and Apel, H.: Floodplain hydrology of the Mekong Delta, Vietnam, Hydrological Processes, 26, 674-686, 10.1002/hyp.8183, 2012.

IPCC: Climate Change 2014: Synthesis Report. Contribution of Working Groups I, II and III to the Fifth Assessment Report of the Intergovernmental Panel on Climate Change, in, Geneva, Switzerland, 151, 2014. 
Kondolf, G. M., Rubin, Z. K., and Minear, J. T.: Dams on the Mekong: Cumulative sediment starvation, Water Resources Research, 50, 5158-5169, doi:10.1002/2013WR014651, 2014

Kondolf, G. M., Schmitt, R. J., Carling, P., Darby, S., Arias, M., Bizzi, S., Castelletti, A., Cochrane, T. A., Gibson, S., and Kummu, M.: Changing sediment budget of the Mekong: Cumulative threats and management strategies for a large river basin, Science of The Total Environment, 625, 114-134, 2018.

Kreibich, H., Di Baldassarre, G., Vorogushyn, S., Aerts, J. C. J. H., Apel, H., Aronica, G. T., Arnbjerg-Nielsen, K., Bouwer, L. M., Bubeck, P., Caloiero, T., Chinh, D. T., Cortès, M., Gain, A. K., Giampá, V., Kuhlicke, C., Kundzewicz, Z. W., Llasat, M. C., Mård, J., Matczak, P., Mazzoleni, M., Molinari, D., Dung, N. V., Petrucci, O., Schröter, K., Slager, K., Thieken, A. H., Ward, P. J., and Merz, B.: Adaptation to flood risk: Results of international paired flood event studies, Earth's Future, 5, 953-965, 10.1002/2017ef000606, 2017.

Kummu, M., Lu, X., Wang, J., and Varis, O.: Basin-wide sediment trapping efficiency of emerging reservoirs along the Mekong, Geomorphology, 119, 181-197, 2010.

Kummu, M., de Moel, H., Porkka, M., Siebert, S., Varis, O., and Ward, P. J.: Lost food, wasted resources: Global food supply chain losses and their impacts on freshwater, cropland, and fertiliser use, Science of The Total Environment, 438, 477-489, https://doi.org/10.1016/j.scitotenv.2012.08.092, 2012.

Lauri, H., de Moel, H., Ward, P. J., Räsänen, T. A., Keskinen, M., and Kummu, M.: Future changes in Mekong River hydrology: impact of climate change and reservoir operation on discharge, Hydrol. Earth Syst. Sci., 16, 4603-4619, 10.5194/hess-164603-2012, 2012.

Le, T. V. H., Nguyen, H. N., Wolanski, E., Tran, T. C., and Haruyama, S.: The combined impact on the flooding in Vietnam's Mekong River delta of local man-made structures, sea level rise, and dams upstream in the river catchment, Estuarine, Coastal and Shelf Science, 71, 110-116, http://dx.doi.org/10.1016/i.ecss.2006.08.021, 2007.

Leinenkugel, P., Kuenzer, C., Oppelt, N., and Dech, S.: Characterisation of land surface phenology and land cover based on moderate resolution satellite data in cloud prone areas — A novel product for the Mekong Basin, Remote Sensing of Environment, 136, 180-198, http://dx.doi.org/10.1016/j.rse.2013.05.004, 2013.

Manh, N. V., Dung, N. V., Hung, N. N., Merz, B., and Apel, H.: Large-scale suspended sediment transport and sediment deposition in the Mekong Delta, Hydrol. Earth Syst. Sci., 18, 3033-3053, 10.5194/hess-18-3033-2014, 2014

Manh, N. V., Dung, N. V., Hung, N. N., Kummu, M., Merz, B., and Apel, H.: Future sediment dynamics in the Mekong Delta floodplains: Impacts of hydropower development, climate change and sea level rise, Global and Planetary Change, 127, 22 33, 2015.

Minderhoud, P. S. J., Erkens, G., Pham, V. H., Bui, V. T., Erban, L., Kooi, H., and Stouthamer, E.: Impacts of 25 years of groundwater extraction on subsidence in the Mekong delta, Vietnam, Environ Res Lett, 12, 064006, 10.1088/17489326/aa7146, 2017

Minderhoud, P. S. J., Coumou, L., Erkens, G., Middelkoop, H., and Stouthamer, E.: Mekong delta much lower than previously assumed in sea-level rise impact assessments, Nature Communications, 10, 3847, 10.1038/s41467-019-11602-1, 2019.

MRC: Overview of the Hydrology of the Mekong Basin, Mekong River Commission, Vientiane, 73, 2005.

MRC: The Impact and Management of Floods and Droughts in the Lower Mekong Basin and The Implications of Possible Climate Change, Mekong River Commission, 129 pages, 2012.

MRC: Mekong dam database, Mekong River Commision, in, 2015.

Nelson, G. C., Rosegrant, M. W., Palazzo, A., Gray, I., Ingersoll, C., Robertson, R., Tokgoz, S., Zhu, T., Sulser, T. B., and Ringler, C.: Food security, farming, and climate change to 2050: scenarios, results, policy options, Intl Food Policy Res Inst, 2010.

Nhan, N. H., and Cao, N. B.: Chapter 19 - Damming the Mekong: Impacts in Vietnam and Solutions, in: Coasts and Estuaries, edited by: Wolanski, E., Day, J. W., Elliott, M., and Ramachandran, R., Elsevier, 321-340, 2019.

Pearse-Smith, S. W. D.: The impact of continued Mekong Basin hydropower development on local livelihoods, 2012.

Pokhrel, Y., Burbano, M., Roush, J., Kang, H., Sridhar, V., and Hyndman, W. D.: A Review of the Integrated Effects of Changing Climate, Land Use, and Dams on Mekong River Hydrology, Water, 10, 10.3390/w10030266, 2018a.

Pokhrel, Y., Shin, S., Lin, Z., Yamazaki, D., and Qi, J.: Potential Disruption of Flood Dynamics in the Lower Mekong River Basin Due to Upstream Flow Regulation, Scientific Reports, 8, 17767, 10.1038/s41598-018-35823-4, 2018b.

Räsänen, T. A., Someth, P., Lauri, H., Koponen, J., Sarkkula, J., and Kummu, M.: Observed river discharge changes due to hydropower operations in the Upper Mekong Basin, Journal of Hydrology, 545, 28-41, https://doi.org/10.1016/j.jhydrol.2016.12.023, 2017.

Reis, N.: Flood Management and Development Planning. The Allocation of Risk in the Mekong Delta, Vietnam, in, April 27, Bonn International Graduate School for Development Research (BIGS-DR), 17, 2007.

Schmitt, R. J. P., Bizzi, S., Castelletti, A., and Kondolf, G. M.: Improved trade-offs of hydropower and sand connectivity by strategic dam planning in the Mekong, Nature Sustainability, 1, 96-104, 10.1038/s41893-018-0022-3, 2018.

Smajgl, A., Toan, T. Q., Nhan, D. K., Ward, J., Trung, N. H., Tri, L. Q., Tri, V. P. D., and Vu, P. T.: Responding to rising sea levels in the Mekong Delta, Nature Clim. Change, 5, 167-174, 10.1038/nclimate2469, 2015. 
Takagi, H., Ty, T. V., and Thao, N. D.: 12 - Investigation on Floods in Can Tho City: Influence of Ocean Tides and Sea Level Rise for the Mekong Delta's Largest City, in: Coastal Disasters and Climate Change in Vietnam, edited by: Thao, N. D., Takagi, H., and Esteban, M., Elsevier, Oxford, 257-274, 2014.

Tessler, Z. D., Vörösmarty, C. J., Grossberg, M., Gladkova, I., Aizenman, H., Syvitski, J. P. M., and Foufoula-Georgiou, E.: Profiling risk and sustainability in coastal deltas of the world, Science, 349, 638-643, 10.1126/science.aab3574, 2015.

Toan, T. Q.: Climate Change and Sea Level Rise in the Mekong Delta: Flood, Tidal Inundation, Salinity Intrusion, and Irrigation Adaptation Methods, in: Coastal Disasters and Climate Change in Vietnam, edited by: Esteban, N. D. T., Hiroshi Takagi Miguel, Elsevier, Oxford, 199-218, 2014.

Tran, D. D., van Halsema, G., Hellegers, P. J. G. J., Ludwig, F., and Wyatt, A.: Questioning triple rice intensification on the Vietnamese mekong delta floodplains: An environmental and economic analysis of current land-use trends and alternatives, Journal of Environmental Management, 217, 429-441, https://doi.org/10.1016/j.jenvman.2018.03.116, 2018a.

Tran, D. D., van Halsema, G., Hellegers, P. J. G. J., Phi Hoang, L., Quang Tran, T., Kummu, M., and Ludwig, F.: Assessing impacts of dike construction on the flood dynamics of the Mekong Delta, Hydrol. Earth Syst. Sci., 22, 1875-1896, 10.5194/hess-221875-2018, 2018b.

Tri, V.: Hydrology and Hydraulic Infrastructure Systems in the Mekong Delta, Vietnam, in: The Mekong Delta System, edited by: Renaud, F. G., and Kuenzer, C., Springer Environmental Science and Engineering, Springer Netherlands, 49-81, 2012.

Triet, N. V. K., Dung, N. V., Fujii, H., Kummu, M., Merz, B., and Apel, H.: Has dyke development in the Vietnamese Mekong Delta shifted flood hazard downstream?, Hydrol. Earth Syst. Sci., 21, 3991-4010, 10.5194/hess-21-3991-2017, 2017.

Triet, N. V. K., Dung, N. V., Merz, B., and Apel, H.: Towards risk-based flood management in highly productive paddy rice cultivation - concept development and application to the Mekong Delta, Natural Hazards and Earth System Sciences, 18, 2859-2876, 10.5194/nhess-18-2859-2018, 2018.

Van Binh, D., Kantoush, S., and Sumi, T.: Changes to long-term discharge and sediment loads in the Vietnamese Mekong Delta caused by upstream dams, Geomorphology, 107011, https://doi.org/10.1016/j.geomorph.2019.107011, 2019.

Van, P., Popescu, I., Van Griensven, A., Solomatine, D., Trung, N., and Green, A.: A study of the climate change impacts on fluvial flood propagation in the Vietnamese Mekong Delta, Hydrology and Earth System Sciences, 16 (12), 2012, 2012.

Van, T. C.: Identification of sea level rise impacts on the Mekong Delta and orientation of adaptation activities, in, 2009.

Wang, J., Feng, L., Tang, X., Bentley, Y., and Höök, M.: The implications of fossil fuel supply constraints on climate change projections: A supply-side analysis, Futures, 86, 58-72, https://doi.org/10.1016/j.futures.2016.04.007, 2017.

Ziv, G., Baran, E., Nam, S., Rodríguez-Iturbe, I., and Levin, S. A.: Trading-off fish biodiversity, food security, and hydropower in the Mekong River Basin, Proceedings of the National Academy of Sciences, 201201423, 2012. 


\section{Supplement}

Table S1. Changes in simulated annual maximum water level (AMWL) for the dry year

\begin{tabular}{|c|c|c|c|c|c|c|c|c|}
\hline & \multirow{2}{*}{$\begin{array}{c}\text { AMWL at BL } \\
\text { [meter] }\end{array}$} & \multicolumn{7}{|c|}{ Changes in modelled AMWL compared to control runs (in centimetres) } \\
\hline & & S1-HP & S2-FR & S3-DE & S4-CC & S5-SLR & S6-BAU & S7-SD \\
\hline Tan Chau [1] & 2.52 & -33 & 0 & 0 & 23 & 22 & 12 & $\overline{40}$ \\
\hline Vam Nao [2] & 2.01 & -17 & 0 & 0 & 9 & 28 & 20 & 36 \\
\hline Cao Lanh [3] & 1.70 & -1 & 0 & 0 & 4 & 34 & 37 & 39 \\
\hline My Thuan [4] & 1.55 & 0 & 0 & 0 & 0 & 40 & 43 & 41 \\
\hline Chau Doc [5] & 2.27 & -31 & 0 & 0 & 21 & 22 & 10 & 40 \\
\hline Long Xuyen [6] & 1.80 & -7 & 0 & 0 & 3 & 32 & 29 & 35 \\
\hline Can Tho [7] & 1.62 & 0 & 0 & 0 & 2 & 39 & 41 & 41 \\
\hline Dai Ngai [8] & 1.77 & 0 & 0 & 0 & 0 & 42 & 43 & 43 \\
\hline Xuan To [9] & 1.91 & -52 & 0 & 0 & 40 & 34 & 14 & 59 \\
\hline Tri Ton [10] & 1.24 & -21 & 0 & 0 & 8 & 32 & 22 & 38 \\
\hline Tan Hiep [11] & 0.88 & -3 & 0 & 0 & 4 & 32 & 33 & 35 \\
\hline Vi Thanh [12] & 0.69 & 0 & 0 & 0 & 0 & 42 & 43 & 42 \\
\hline Moc Hoa [13] & 1.31 & -14 & 0 & 0 & 4 & 25 & 20 & 28 \\
\hline Hung Thanh [14] & 1.52 & -18 & 0 & 0 & 7 & 21 & 16 & 28 \\
\hline Kien Binh [15] & 1.00 & -7 & 0 & 0 & 0 & 30 & 31 & 32 \\
\hline Tan An [16] & 1.20 & 0 & 0 & 0 & 0 & 39 & 40 & 39 \\
\hline
\end{tabular}

Table S2. Changes in simulated annual maximum water level (AMWL) for the normal year

\begin{tabular}{lcrrrrrrr}
\hline & AMWL at BL & \multicolumn{3}{c}{ Changes in modelled AMWL compared to control runs (in centimetres) } \\
& [meter] & S1-HP & S2-FR & S3-DE & S4-CC & S5-SLR & S6-BAU & S7-SD \\
\hline Tan Chau [1] & 3.47 & -66 & -3 & 2 & 21 & 14 & 0 & 29 \\
Vam Nao [2] & 2.60 & -45 & -2 & 2 & 12 & 21 & 9 & 27 \\
Cao Lanh [3] & 1.96 & -12 & -1 & 2 & 8 & 32 & 33 & 40 \\
My Thuan [4] & 1.66 & -3 & 0 & 0 & 7 & 38 & 40 & 45 \\
Chau Doc [5] & 3.21 & -69 & -5 & 1 & 24 & 14 & 2 & 31 \\
Long Xuyen [6] & 2.08 & -16 & -1 & 1 & 4 & 31 & 27 & 35 \\
Can Tho [7] & 1.77 & -6 & -1 & 0 & 6 & 37 & 38 & 42 \\
Dai Ngai [8] & 1.82 & -1 & 0 & 0 & 3 & 43 & 44 & 45 \\
Xuan To [9] & 3.14 & -74 & -5 & 1 & 28 & 14 & 1 & 33 \\
Tri Ton [10] & 1.92 & -53 & -3 & 2 & 8 & 14 & 5 & 24 \\
Tan Hiep [11] & 1.18 & -18 & 0 & 1 & 4 & 21 & 20 & 28 \\
Vi Thanh [12] & 0.74 & -1 & 0 & 0 & 2 & 40 & 41 & 42 \\
Moc Hoa [13] & 1.75 & -36 & 0 & 3 & 16 & 21 & 15 & 36 \\
Hung Thanh [14] & 2.00 & -38 & -1 & 4 & 21 & 18 & 16 & 34 \\
Kien Binh [15] & 1.17 & -13 & 0 & 1 & 12 & 31 & 33 & 42 \\
Tan An [16] & 1.24 & -2 & 0 & 0 & 5 & 38 & 39 & 43 \\
\hline
\end{tabular}


Table S3. Changes in simulated annual maximum water level (AMWL) for the wet year

\begin{tabular}{lccrrrrrr}
\hline & AMWL at BL & \multicolumn{2}{c}{ Changes in modelled AMWL compared to control runs (in centimetres) } \\
& [meter] & S1-HP & S2-FR & S3-DE & S4-CC & S5-SLR & S6-BAU & S7-SD \\
\hline Tan Chau [1] & 3.67 & -42 & -3 & 2 & 33 & 13 & 17 & 40 \\
Vam Nao [2] & 2.73 & -28 & -2 & 2 & 26 & 20 & 25 & 40 \\
Cao Lanh [3] & 2.04 & -9 & -1 & 1 & 16 & 33 & 39 & 44 \\
My Thuan [4] & 1.72 & -4 & 0 & 0 & 6 & 39 & 42 & 45 \\
Chau Doc [5] & 3.41 & -43 & -4 & 2 & 35 & 13 & 17 & 41 \\
Long Xuyen [6] & 2.15 & -10 & -1 & 1 & 15 & 29 & 36 & 41 \\
Can Tho [7] & 1.84 & -6 & -1 & 0 & 7 & 35 & 39 & 43 \\
Dai Ngai [8] & 1.85 & -1 & 0 & 0 & 3 & 42 & 44 & 45 \\
Xuan To [9] & 3.38 & -48 & -6 & 1 & 35 & 12 & 15 & 39 \\
Tri Ton [10] & 2.03 & -28 & -2 & 4 & 30 & 11 & 26 & 47 \\
Tan Hiep [11] & 1.22 & -8 & 0 & 1 & 16 & 23 & 30 & 37 \\
Vi Thanh [12] & 0.76 & -1 & 0 & 1 & 4 & 41 & 43 & 44 \\
Moc Hoa [13] & 1.88 & -26 & -1 & 3 & 40 & 23 & 34 & 56 \\
Hung Thanh [14] & 2.16 & -29 & -1 & 2 & 32 & 16 & 25 & 45 \\
Kien Binh [15] & 1.25 & -10 & 0 & 0 & 15 & 31 & 36 & 44 \\
Tan An [16] & 1.27 & -3 & 0 & 0 & 5 & 38 & 40
\end{tabular}

Table S4. Changes in simulated maximum inundation extent and duration according to different scenarios

\begin{tabular}{|c|c|c|c|c|c|c|c|c|}
\hline & \multirow{2}{*}{$\begin{array}{l}\text { BL inundation } \\
\text { (\% of delta area) }\end{array}$} & \multicolumn{7}{|c|}{ Changes from baseline runs (in percentage) } \\
\hline & & S1-HP & S2-FR & S3-DE & S4-CC & S5-SLR & S6-BAU & S7-SD \\
\hline \multicolumn{9}{|l|}{ Dry year } \\
\hline No inundation & 53.2 & 1.0 & -0.4 & 0.1 & -0.8 & -20.0 & -19.5 & -22.6 \\
\hline$<1$ month & 17.2 & 0.3 & 0.1 & 0.0 & -0.3 & -9.9 & -9.8 & -10.0 \\
\hline$<2$ month & 9.3 & -0.1 & 0.1 & 0.0 & 0.1 & -1.5 & -0.8 & -1.2 \\
\hline$<3$ month & 7.3 & -0.6 & 0.2 & -0.1 & 0.1 & 2.7 & 1.6 & 2.4 \\
\hline$<4$ month & 4.2 & -0.3 & 0.0 & 0.0 & 0.6 & 1.8 & 1.6 & 3.9 \\
\hline$>4$ month & 8.8 & -0.1 & 0.0 & 0.0 & 0.3 & 26.8 & 26.8 & 27.4 \\
\hline \multicolumn{9}{|l|}{ Normal year } \\
\hline No inundation & 43.3 & 7.7 & -1.7 & 1.6 & -2.5 & -19.4 & -16.5 & -25.6 \\
\hline$<1$ month & 16.3 & 0.4 & 0.1 & 0.0 & -0.4 & -10.2 & -10.0 & -10.0 \\
\hline$<2$ month & 11.1 & -1.7 & 0.3 & -0.3 & 1.9 & -3.8 & -1.7 & -1.2 \\
\hline$<3$ month & 11.2 & -3.1 & 1.0 & -0.9 & 2.0 & 1.7 & 2.8 & 6.3 \\
\hline$<4$ month & 6.6 & -1.5 & 0.2 & -0.4 & -0.1 & 3.5 & 0.1 & 3.7 \\
\hline$>4$ month & 11.5 & -1.8 & 0.1 & -0.1 & -0.9 & 28.1 & 25.4 & 26.8 \\
\hline \multicolumn{9}{|l|}{ Wet year } \\
\hline No inundation & 40.5 & 5.1 & -5.5 & -0.4 & -7.1 & -21.1 & -19.0 & -29.6 \\
\hline$<1$ month & 15.8 & 0.9 & -0.3 & -0.5 & -1.4 & -10.3 & -10.5 & -10.8 \\
\hline$<2$ month & 10.6 & 0.1 & 0.0 & -0.8 & -1.2 & -4.2 & -4.4 & -4.6 \\
\hline$<3$ month & 11.3 & -1.2 & 1.2 & -0.8 & 0.1 & 0.3 & -0.9 & 1.1 \\
\hline$<4$ month & 10.5 & -3.4 & 4.8 & 2.8 & 7.4 & 7.7 & 7.1 & 12.4 \\
\hline$>4$ month & 11.2 & -1.4 & -0.2 & -0.3 & 2.2 & 27.6 & 27.6 & 31.4 \\
\hline
\end{tabular}




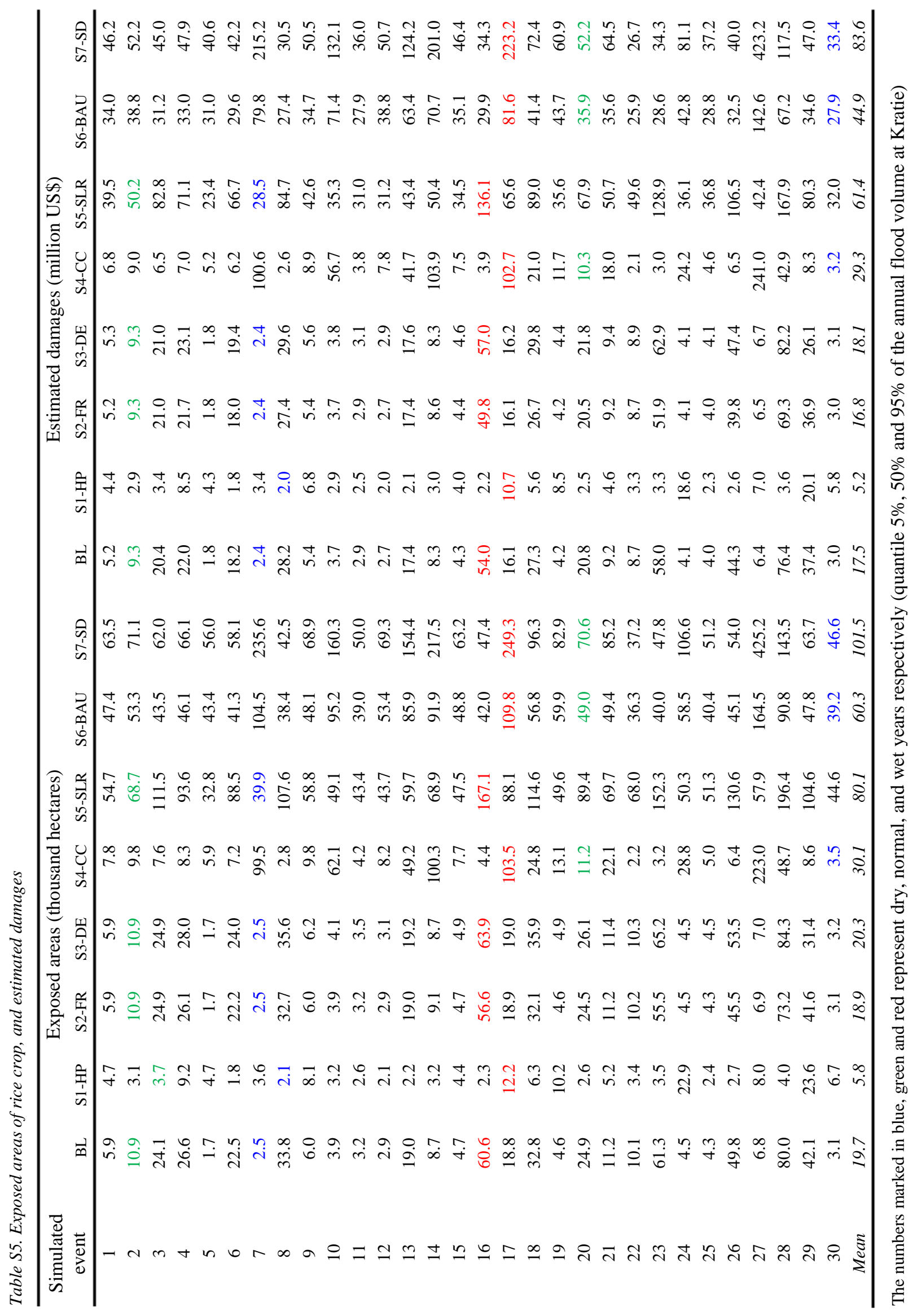



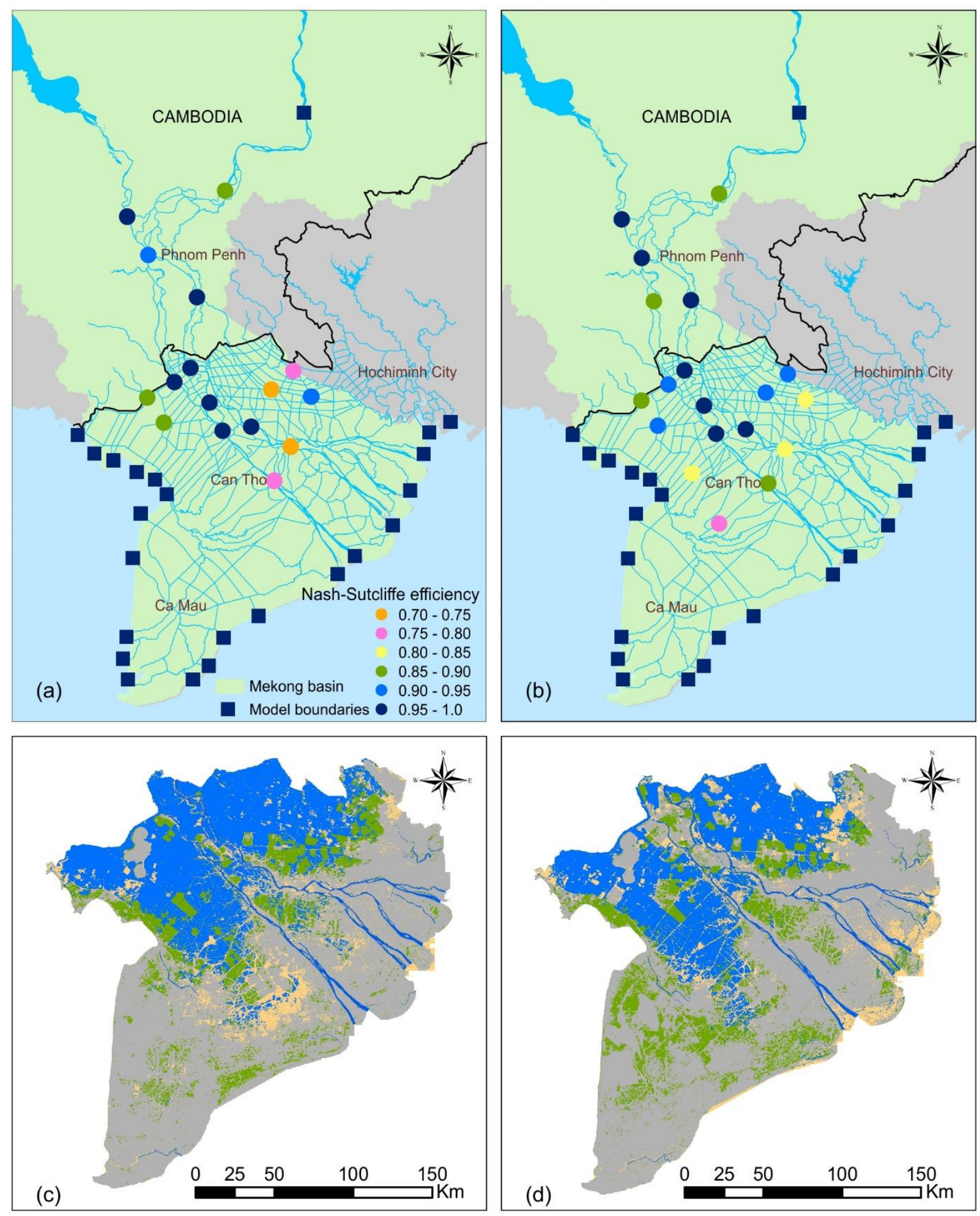

sim. dry / obs. wet sim. wet / obs. wet sim. dry / obs. dry sim. wet / obs. dry

Figure S1. Model performance: comparison of gauged and simulated water level for the 2000 flood (a) and 2011 flood (b); comparison of observed i.e. derived from satellite data and simulated maximum inundation extent for the floods in 2000 (c) and 2011 (d), adopted from Triet et al. (2017). 